University of Wollongong

Research Online

Faculty of Engineering and Information

Faculty of Engineering and Information

Sciences - Papers: Part B

Sciences

2017

Experimental investigation of composite beams reinforced with GFRP Ibeam and steel bars

Muhammad N. S Hadi

University of Wollongong, mhadi@uow.edu.au

Jiansong Yuan

University of Wollongong, jy960@uowmail.edu.au

Follow this and additional works at: https://ro.uow.edu.au/eispapers1

Part of the Engineering Commons, and the Science and Technology Studies Commons

Research Online is the open access institutional repository for the University of Wollongong. For further information contact the UOW Library: research-pubs@uow.edu.au 


\title{
Experimental investigation of composite beams reinforced with GFRP I-beam and steel bars
}

\begin{abstract}
This paper presents results of an experimental study on the flexural behaviour of a composite beam, which is reinforced with longitudinal tensile steel bars as well as glass fibre reinforced polymer (GFRP) pultruded I-beam encased in concrete. Five beam specimens, including one traditional reinforced concrete (RC) beam and four composite beams, were cast and tested under four-point bending. The variables involved in the composite beams include the type of longitudinal tensile bars (steel bars and GFRP bars) and the location of the I-beam in the cross-section (middle and a shift of $30 \mathrm{~mm}$ towards the tension region). The test results presented in this study show that the proposed composite beams have a very ductile response due to the existence of the tensile steel bars, and the yield point of the composite beam is controlled by the tensile steel bars. The ultimate load of the proposed composite beam in this study is higher than the traditional RC beam in this study, and the ultimate load is governed by the encased I-beam. When GFRP bars were used to replace the tensile steel bars to reinforce the composite beams, the brittle failure of GFRP bars caused lack of ductility of the beam members, and both the stiffness and ultimate load were reduced significantly. Compared with steel bars, the slip between the concrete and the I-beam was also increased when GFRP bars were used. The different location of the Ibeam has little effect on the flexural response.
\end{abstract}

\section{Keywords}

gfrp, reinforced, beams, composite, investigation, bars, experimental, steel, i-beam

Disciplines

Engineering | Science and Technology Studies

\section{Publication Details}

Hadi, M. N. S. \& Yuan, J. (2017). Experimental investigation of composite beams reinforced with GFRP Ibeam and steel bars. Construction and Building Materials, 144 462-474. 


\section{Experimental investigation of composite beams reinforced with GFRP I-} beam and steel bars

School of Civil, Mining and Environmental Engineering, University of Wollongong,

Correspondence:

20 Muhammad N. S. Hadi

21 School of Civil, Mining \& Environmental Engineering

22 University of Wollongong, Australia

23 E-mail:mhadi@uow.edu.au

24 Telephone: + 61242214762

25 Facsimiles: + 61242213238

26

27

28

$29 *$ Corresponding author 
 \\ Experimental Investigation of Composite beams Reinforced with GFRP I-}

34 Abstract: This paper presents results of an experimental study on the flexural behaviour of a composite beam, which is reinforced with longitudinal tensile steel bars as well as glass fibre reinforced polymer (GFRP) pultruded I-beam encased in concrete. Five beam specimens, including one traditional reinforced concrete (RC) beam and four composite beams, were cast and tested under four-point bending. The variables involved in the composite beams include the type of longitudinal tensile bars (steel bars and GFRP bars) and the location of the I-beam in the cross-section (middle and a shift of $30 \mathrm{~mm}$ towards the tension region). The test results presented in this study show that the proposed composite beams have a very ductile response due to the existence of the tensile steel bars, and the yield point of the composite beam is controlled by the tensile steel bars. The ultimate load of the proposed composite beam in this study is higher than the traditional RC beam in this study, and the ultimate load is governed by the encased I-beam. When GFRP bars were used to replace the tensile steel bars to reinforce the composite beams, the brittle failure of GFRP bars caused lack of ductility of the beam members, and both the stiffness and ultimate load were reduced significantly. Compared with steel bars, the slip between the concrete and the I-beam was also increased when GFRP bars were used. The different location of the I-beam has little effect on the flexural response.

Keywords: Composite beams; GFRP; I-beam, Ductility; Flexural behaviour. 


\section{Research Highlights}

51 GFRP I-beam is encased in concrete to reinforce the concrete beam.

52 Flexural behaviour of I-beam in composite beam is assessed.

53 Tensile steel bars are used to improve the ductility of the composite beam reinforced with I-beam.

54 Location of I-beam affects the ultimate load of the composite beam. 


\section{1. Introduction}

56 Fibre Reinforced Polymer (FRP) is increasingly used in civil engineering construction in the last two decades because of the excellent properties of corrosion resistance as well as high strength-to-weight ratio. Extensive research studies have been conducted on using FRP to retrofit existing structures [14]. On the other hand, FRP composites (such as FRP bars and FRP pultruded profiles) are also exploited as a kind of standard construction product in new construction [5-8]. Due to the advantages of convenient installation and the customized cross-sections (e.g. I-beam, square tube or circular tube), the application of the FRP pultruded profiles have been extensively explored in recent years.

The FRP pultruded profiles are suitable for use as all FRP structures such as building floor, cooling towers and offshore platforms [9-11]. Moreover, it can be used in combination with other materials to develop composite structures. A few studies were carried out to use the GFRP I-beam to reinforce the beam specimens, thus forming a composite structural member. Two types of representative composite beams are shown in Fig. 1. The composite beam with Cross-section A (Fig. 1a) is composed of a concrete block on the top and an I-beam at the bottom [12]. In this case, the concrete is intended for compression and the I-beam for tension. Nevertheless, the disadvantage of instability at the web could not be ignored during the loading. In addition, the fire performance of such composite beam is poor since the I-beam is exposed to air without the protection of the concrete cover. The other type of composite beam with Cross-section B (Fig. 1b) was proposed by encasing the I-beam in the middle of the cross-section [13]. Compared with the composite beams with Cross-section A, the stability and the fire performance are improved in this type of composite beams. Nevertheless, both FRP and concrete are poor in ductility, thus causing a brittle failure of this type of composite beam.

In order to improve the flexural response of the composite beam reinforced with the I-beam, a type of the composite beam is proposed in this study. As shown in Fig. 1c, the composite beam is reinforced 
with the I-beam and the longitudinal tensile steel bars, and the I-beam is encased in concrete. The encased I-beam is contributed to the improvement of the flexural strength and the corrosion resistance of the beam members. The tensile steel bars used in this composite beam aim to ensure enough bending stiffness and the ductility of the composite beams. The concept of incorporating FRP and steel materials together to enhance the ductility of structure has been proven to be effective by both experimental and numerical approaches [14-20]. Steel stirrups are employed to confine the concrete and enhance the shear strength of the beam members.

The advantages of this type of composite beams are apparent when compared with the existing composite beams reinforced with steel I-section or GFRP I-beam. Compared with the common composite beam reinforced with steel I-section, although the configurations of both are similar, the self-weight of the proposed composite beam is reduced and the corrosion resistance is improved due to the existence of the I-beam. Compared with the composite beam reinforced with GFRP I-beam as shown in Fig. 1a or Fig. 1b, the advantages of this type of composite beam include: (a) the fire performance can be improved because the I-beam is protected by the surrounding concrete; (b) the stability of the I-beam is improved because it is encased in concrete; and (c) the ductility can be improved due to the application of the tensile steel bars. In addition, this type of composite beam also has significant advantages in practical applications, such as: (a) all the materials are standard building materials without special treatment like drilling holes, riveting or welding; and (b) ease for connection to columns due to the presence of the inside steel bars.

This paper aims to investigate the flexural behaviour of this type of composite beams. A total of five beam specimens, including one traditional RC beam and four composite beams, were cast and tested under four-point bending. The ultimate load, bending stiffness and failure modes of the beam specimens were studied. Finally, the flexural strength provided by the I-beam and the slip between the I-beam and concrete were discussed to evaluate the effect of the I-beam in such composite beams. 


\section{Experimental program}

\subsection{Beam specimens}

A total of five beam specimens were cast and tested in this experimental study, and the details of the specimens and the configurations of the cross-section are shown in Table 1 and Fig. 2, respectively. All the specimens had an overall length of $2040 \mathrm{~mm}$ and a cross-section of $350 \times 200 \mathrm{~mm}$. The label of the reference specimen is RC. For the remaining four specimens, the label of the specimens represents the type of tensile bars and the location of the I-beam. The first letter $(\mathrm{S} / \mathrm{F})$ in the label indicates the type of longitudinal tensile bars used in the specimen, steel bars (S) or GFRP bars (F). The letter followed by a number which indicates the reinforcement ratio of the specimens in percent, and the last letter M/B (middle/bottom) in the label is the location of the I-beam. For instance, Specimen S0.57B indicates the specimen which is reinforced by the steel reinforcement with a reinforcement ratio of $0.57 \%$, and the I-beam is located at the bottom of the beam specimen.

The specimens were divided into three groups, namely, Reference group, Group S and Group F. The first group is a reference group, which includes a traditional reinforced concrete beam. This beam was reinforced with four tensile steel deformed bars with $16 \mathrm{~mm}$ nominal diameter and $500 \mathrm{MPa}$ nominal tensile strength. The reinforcement ratio of this beam specimen was $1.1 \%$, and it was designed as under-reinforced beam to ensure the specimens will fail in flexure. Group S contains two proposed composite beams. Specimen S0.57M was reinforced with the I-beam and two tensile steel deformed bars with $16 \mathrm{~mm}$ nominal diameter and $500 \mathrm{MPa}$ nominal tensile strength (Fig. 2b), and the I-beam was placed in the middle of the cross-section. Because the location of the tensile material could affect the flexural capacity of the beam members $[16,21,22]$, the I-beam in Specimen S0.57B was transferred by $30 \mathrm{~mm}$ from the middle to the bottom of the cross-section. Besides the different location of the I-beam, the other configurations in Specimen S0.57B were identical with those in Specimen S0.57M. Moreover, in order to investigate the influence of the steel bars on the ductility of the beam specimens, the tensile steel bars in Group $\mathrm{S}$ were replaced by three GFRP longitudinal bars 
with $12 \mathrm{~mm}$ diameter in Group F. For example, Specimen F0.46M was reinforced with the I-beam and

133 three GFRP longitudinal bars as shown in Fig. 2d. The I-beam was shifted down by $30 \mathrm{~mm}$ in 134 Specimen F0.46B.

Transverse steel stirrups with hook angle of $135^{\circ}$ were used in all the specimens. In order to facilitate the installation of the stirrups, two steel bars in the compression side were used as hangers for the stirrups. The steel stirrups and two steel bars in the compression side had plain $10 \mathrm{~mm}$ diameter with a nominal tensile strength of $250 \mathrm{MPa}$. The stirrups were spaced at $60 \mathrm{~mm}$ in the shear span and $80 \mathrm{~mm}$

140 in the pure bending region.

\subsection{Material properties}

The concrete was supplied by a local company with $120 \mathrm{~mm}$ slump. Cylinders with $100 \mathrm{~mm}$ diameter and $200 \mathrm{~mm}$ height were cast and cured in the curing tank. The average compressive strength at 7 and 28 days were 20.8 MPa and 31.8 MPa, respectively. Tensile testing on three steel bars was conducted for each type of steel bars according to AS 1391 [23], and Table 2 shows the experimental tensile strength and modulus of elasticity of the steel bars.

The GFRP bars with a smooth surface and a nominal diameter of $12 \mathrm{~mm}$ were provided by the Treadwell Group Company [24]. Due to the smooth surface of the GFRP bars, the nominal area was used for the stress calculation. Sand was manually coated onto the surface of the GFRP bars to enhance the bond strength between the surrounding concrete and the bars. The tensile testing was conducted by following ASTM D7205 / D7205M [25], and the length of the coupon was $1300 \mathrm{~mm}$. Two steel tubes were used as anchors and were fixed by expansive cement at the two ends of GFRP bars, as shown in Fig. 3a. The steel tube had a length of $400 \mathrm{~mm}$, and the outer diameter and inner diameter were $40 \mathrm{~mm}$ and $30 \mathrm{~mm}$, respectively. During the test, a layer of plastic wrap was wrapped onto the GFRP bars to eliminate the explosion of fibres from the bars at failure (Fig. 3b). Five samples of GFRP bars were tested, and the test results are given in Table 2. 
159 The I-beam $(200 \mathrm{~mm} \times 100 \mathrm{~mm} \times 10 \mathrm{~mm} /$ Height $\times$ Width $\times$ Thickness $)$ used in this study was

160 manufactured by pultrusion method by Treadwell Group Company [24]. The material testing of the I-

161 beam included compressive and tensile properties at both the flange and the web. Coupons for the material testing were cut from the I-beam as shown in Fig. 4. All the material testing was conducted in the longitudinal directions. The compressive testing was conducted in accordance with ASTM D695 [26] and the nominal dimension of the coupon is $12.7 \mathrm{~mm} \times 38.1 \mathrm{~mm}$. The tensile strength was determined in accordance with ISO 527 [27] and the nominal dimension of the coupon is $25 \mathrm{~mm} \times$ $250 \mathrm{~mm}$. Five coupons were tested to determine the average tensile or compressive strength, and the test results are presented in Table 3.

\subsection{Fabrication of beam specimens}

First, five steel cages were made using thin steel wires to tie the stirrups and the longitudinal bars. Afterwards, in order to fix the I-beam in the composite beams, the short steel wires were inserted into the flanges to eliminate any possible movement during the concrete casting as shown in Fig. 5a. Two timber blocks were placed under the I-beam to adjust the location of the I-beam in the middle or the bottom of the cross-section. Before moving the steel cages and the I-beams into the formwork as shown in Fig. 5b, the plastic chairs were applied at the bottom of the steel cages to ensure $20 \mathrm{~mm}$ cover. Due to the large size of the specimens, all the beam specimens were cured at ambient temperature. A wet hessian was placed over the specimens to prevent the moisture loss, and the specimens were watered during weekdays until the test day.

\subsection{Instrumentation and test setup}

As shown in Fig. 6, all the specimens were simply supported and subjected to four-point bending. Each of the beam specimens had a clear span of $1740 \mathrm{~mm}$ and shear span of $670 \mathrm{~mm}$. The length of the pure bending region was $400 \mathrm{~mm}$. For each specimen, five linear variable differential transformers (LVDTs) (1-5) were placed to monitor the deflection at different locations. Due to the possible brittle failure of the composite beams, the four LVDTs in the shear span (Fig. 7a) were removed once the 
applied load reached $200 \mathrm{kN}$, which was about $50 \%$ of the expected ultimate load. The LVDT in the midspan was used to measure the deflection until the failure of the specimen. The wire rope of this LVDT was fixed at the bottom of the beam specimens, and the midspan deflection of the beam specimen could be measured according to the change of the length of the wire rope. A steel cover was made to protect this LVDT from the dropped concrete pieces (Fig. 7b).

191

A series of strain gauges were bonded on the longitudinal bars and the I-beams. For Specimen RC, two strain gauges (S1 and S2) were bonded at the midspan of the compressive bars and the other two (S3 and S4) on the tensile bars (Fig. 8a). For the composite beams, one strain gauge was bonded at the midspan of the longitudinal tensile bar (S10) and one at the compressive bar (S5), and four additional strain gauges were evenly bonded at the midspan of the I-beam, two at the flanges (S6 and S9) and two at the web (S7 and S8). All the strain gauges were placed in the longitudinal direction in this study.

The displacement-controlled load was applied using the $1000 \mathrm{kN}$ actuator. The loading rate was $1 \mathrm{~mm}$ per minute. Once the load reduced $80 \%$ of the ultimate load, the test of Specimen RC was stopped. For the composite beams, the specimens were considered to have failed once the tensile steel bars or GFRP longitudinal bars ruptured. All the test data were collected by a data logger.

\section{Experimental results}

The experimental results are summarized in Table 4 . The yield load $\left(P_{y}\right)$, ultimate load $\left(P_{u}\right)$, failure mode and ultimate moment $\left(M_{u}\right)$ have been presented. The yield load only occurred at Specimen RC and the composite beam specimens in Group S (S0.57M and S0.57B). Moreover, the bending stiffness, failure modes and crack propagation, as well as the slip between the I-beam and the concrete are analysed in the sections as below. 
213 The load-midspan deflection curves are shown in Fig. 9. For the proposed composite beams in Group

214 S, the ultimate load of Specimen S0.57M showed an $8 \%$ increase than that of Specimen RC, and the 215 increase for Specimen S0.57B was about 5\%. While in Group F, Specimen F0.46M and Specimen 216 F0.46B showed lower ultimate loads than Specimen RC.

The two proposed composite beams (Specimen S0.57M and Specimen S0.57B) in Group S exhibited similar load-midspan deflection curves. The two curves had obvious yield points during the tests. For Group S, the stage before the yield points (A) was named as Stage (O-A), and the curve between the yield point (A) and the ultimate point (B) was named as Stage (A-B) (Fig. 9). In Stage (O-A), the two curves had similar bending stiffness, and the loads of which increased to about $300 \mathrm{kN}$ where the two specimens yielded. Afterwards, the two curves increased in Stage (A-B) with similar slopes until the ultimate loads were reached. The ultimate load of Specimen S0.57M was $413 \mathrm{kN}$ and it was $400 \mathrm{kN}$ for Specimen S0.57B. After the ultimate loads, these two specimens failed and the loads started to decrease gradually. Finally, the curves of the two specimens experienced two sudden drops, which were caused by the rupture of the two tensile steel bars. The tests were terminated after the rupture of all the tensile steel bars.

In Group F, the load-midspan deflection curves of the two specimens also showed a similar trend. Initially, the two curves showed almost linear increase and reached the ultimate load, $357 \mathrm{kN}$ for Specimen F0.46M and $339 \mathrm{kN}$ for Specimen F0.46B. Afterwards, the specimens failed and the load dropped suddenly, which was accompanied with continuous loud noise. The rupture of the GFRP bars could be observed at the same time. Finally, the beam specimens were still able to carry a stable but lower load. The tests of these two composite beam specimens were terminated due to the large slip between the I-beam and the concrete. 
240 The failure modes of all the specimens are clearly shown in Fig. 10. All the specimens failed in 241 flexure. Specimen RC (Fig. 10a) is a traditional under-reinforced beam. As the applied load was increased, the tensile steel bars reached the yield strength and the specimen yielded. Afterwards, the concrete in the compression zone was crushed. Several shear cracks were observed within the shear span during the test.

For Specimen S0.57M (Fig. 10b), several tiny cracks within the pure bending region were revealed in the initial stage of the test. Further increment of load caused a prominent crack in the midspan, and then this crack propagated through the entire cross-section of the beam specimen. The concrete in the compression side crushed. Finally, the two tensile steel bars ruptured with two loud noises. Specimen S0.57B (Fig. 10c) behaved in a similar failure mode to Specimen S0.57M, but the prominent crack developed more quickly and widely. Lastly, the tensile steel bars ruptured and concrete crushed as well.

For specimens in Group F (F0.46M and F0.46B), which were reinforced with GFRP longitudinal bars and I-beam, one prominent crack occurred below one loading point and then increased rapidly. Furthermore, the GFRP longitudinal bars ruptured suddenly at this crack with the increase of the applied load. The rupture of the GFRP longitudinal bars may be due to the stress concentration that occurred under the loading points. Finally, the beam specimen failed due to the rupture of GFRP longitudinal bars. The concrete in the compression side was still intact without failure when the test was terminated. No obvious cracks were observed within the shear span of the specimens in Group F.

In order to determine the accurate failure modes of the proposed composite beams, the strain-midspan deflection curves and the load-midspan deflection curve of the specimens were compared as shown in Fig. 11. For specimen S0.57M, the strain of the top flanges (S6), the bottom flanges (S9) and the tensile steel bars (S10) were analysed to investigate the failure mode. At Point A, it is clear that the 
tensile steel bars yielded due to the significant increase of the tensile strain, while the strain of the Isection increased steadily. The beam specimen yielded at the same time with the yielding of the tensile steel bars, as such, the tensile steel bars governed the yield point of the composite beams. Afterwards, the ultimate load was observed at Point B and the flanges of the I-beam failed at the same time. Hence, the ultimate load of Specimen S0.57M was controlled by the I-beam. A similar failure mode could be found for Specimen S0.57B as shown in Fig. 11b.

Based on the above discussion, the load-midspan deflection curves of the proposed composite beams were more clearly interpreted. In Stage (O-A) (Fig. 9), the I-beam and tensile steel bars resisted the load together, and then the tensile steel bars yielded at Point A thus leading to the yielding of the composite beam. In Stage (A-B), a further increase of the load was attributed to the superior flexural behaviour of the I-beam. The failure of the I-beam at Point B caused the failure of the composite beam, and the ultimate load was reached at the same time. Afterwards, the specimens showed a very ductile response until the rupture of the tensile steel bars occurred at Point $\mathrm{C}$.

\subsection{Bending stiffness}

282

The bending stiffness $(E I)$ of the beam specimens was compared based on the test results. The bending stiffness is calculated by:

$$
E I=\frac{P L^{2} a}{48 \Delta}\left(3-\frac{4 a^{2}}{L^{2}}\right)
$$

where $P$ is the applied load on the beam specimens, $L$ is the distance between the two supports, $a$ is the distance from the support to the loading point and $\Delta$ is the midspan deflection. It should be noted that although two composite beams in Group S had different stiffness in Stage (O-A) and Stage (A-B), only the stiffness in Stage (O-A) was used in this calculation.

As shown in Table. 5, the difference of stiffness between Specimen RC and the two specimens in Group S was minimal. Therefore, the composite beams reinforced with the I-beam and tensile steel bars had similar bending stiffness compared with Specimen RC. It is believed that the high elastic 
modulus of the tensile steel bars contributes to the high bending stiffness of the beam specimens in Group S. The bending stiffness of both specimens in Group F was just 50\% of that in Group S. The comparison of the bending stiffness between Group S and Group F indicated that the use of the tensile steel bars could improve the bending stiffness of the composite beams reinforced with the I-beam.

\subsection{Ductility}

The ductility definition used in this study $\left(\mu_{E}\right)$ (Eq. 2) is based on the energy theory which was proposed by Naaman and Jeong [28]. This equation could be used for the calculation of the ductility without identifying the yield point of the specimen, and it has been used in some previous studies [13, $29,30]$.

$$
\mu_{E}=\frac{1}{2}\left(\frac{E_{T}}{E_{E}}+1\right)
$$

Where $E_{T}$ is the total energy calculated based on the area under the load-midspan deflection curve. The $E_{E}$ is the elastic energy (Fig. 12), which is computed by the area under the curve of the elastic behaviour. The $P_{f}$ in Fig. 12 is the failure load of the specimen, where the tensile bars in the composite beams ruptured. Traditionally, the weighted value of $S_{1}$ and $S_{2}$ are used to obtain the slope of elastic zone (S) (Eq. 3):

$$
S=\frac{P_{1} S_{1}+\left(P_{2}-P_{1}\right) S_{2}}{P_{2}}
$$

where $S_{1}$ and $S_{2}$ are the slopes of the initial two lines on the load-midspan deflection curve. The $P_{1}$ and $P_{2}$ are the loads at the end of the two lines, respectively. The load-midspan deflection curves in Group F have no obvious two lines, so the ultimate load $\left(P_{u}\right)$ is defined as $P_{2}$, and $P_{l}$ is equal to $0.5 P_{u}$ in this study.

Table 6 shows the ductilities of the beam specimens. In Fig. 13, it is clear that the proposed composite beams in Group S show higher ductility than the other beam specimens. Nevertheless, the ductility of the specimens in Group F was really poor, and the ductility of both specimens was just 1.2. Therefore, it is evident that the tensile steel bars can significantly improve the ductility of the composite beams reinforced with I-beam. 
321 The distribution of cracks at ultimate load in the five specimens is given in Fig. 14, and two different crack development modes were observed for the composite beam specimens. In Group S, the flexural cracks occurred in the pure bending region, and one prominent crack was found within the two loading points. However, in Group F, the prominent crack occurred under one loading point as shown in Fig. 14d and Fig. 14e.

In terms of the number of cracks, it was observed that the composite beams had less cracks than the traditional RC beam. Only few flexural cracks occurred during the test within the pure bending region for the composite beams, and no shear cracks were observed at the shear span. Since all the beam specimens had the same configurations of the stirrups, the disappearance of the shear cracks in the composite beams illustrated that the encased I-beam could improve the shear strength of the beam specimens.

3.6. Slip between the I-beam and the concrete

The slip between the concrete and the I-beam is different for composite beams with different configurations. The relative slip between the I-beam and the concrete was measured by a steel ruler at the end of the test (Fig. 15).

At the beginning of test, no obvious difference of the slip was observed among the composite beams. However, after the ultimate load, two different slip modes were observed between Group S and Group F. In Group S, the slip slowly increased during the test, and the ultimate slip was about $10 \mathrm{~mm}$ as shown in Fig. 15a and Fig. 15b. For the specimens in Group F, the slip gradually increased before the ultimate load was reached. Afterwards, the slip showed a significant increase after the rupture of the

344 GFRP bars until the termination of the test as shown in Fig. 15c and Fig. 15d. It is clear that the development of slip between the I-beam and the concrete was effectively controlled by using tensile steel bars in comparison with GFRP bars. 


\section{Analysis and discussion}

\subsection{Steel bars}

Based on the comparison between Group S and Group F, it is apparent that the proposed composite beams in Group S possess a very ductile response and high ultimate load. The tensile steel bars were significant for the proposed beams in different stages of test. First, due to the higher elastic modulus of the steel, the tensile steel bars offered a higher bending stiffness for the proposed composite beams in Stage (O-A). In Stage (A-B), due to the existence of the tensile steel bars, brittle failure could be avoided and the I-beam contributed to the further increase of the load. Therefore, the I-beam could be more efficiently used in Group S than that in Group F. Finally, the specimens failed at the ultimate load, while the tensile steel bars provided the sufficient ductility to the beam specimens until the rupture of the tensile steel bars.

In general, the tensile steel bars could ensure the I-beams to be used more efficiently, while the brittle failure of the GFRP longitudinal bars limited the performance of the I-beam. For example, the maximum tensile strain of the bottom flange in Specimen S0.57M was 0.00799 and in Specimen S0.57B was 0.00794 , which were about $80 \%$ of the ultimate tensile strain $(0.01)$ in the flange. Nevertheless, the maximum tensile strain of the bottom flange was no more than $70 \%$ of the ultimate strain in Group F, which was only 0.0068 in Specimen F0.46M and 0.0069 in Specimen F0.46B.

\subsection{I-beam}

\subsubsection{Flexural behaviour of the encased I-beam}

The I-beam used in the composite beams provided both shear strength and flexural strength to the composite beams. Through the analysis of the crack propagation, few shear cracks in the composite beams confirmed the improvement of shear resistance offered by the I-beam. In order to evaluate the flexural strength offered by the I-beam, the tensile force provided by the bottom flange and the tensile bars before the ultimate load were compared in Fig. 16. In fact, all the components of the I-beam (the 
web, the top flange and the bottom flange) can provide flexural strength to the composite beams, for simplicity, only the tensile force offered by the bottom flanges were considered in this study.

It is clear that the I-beams showed different performance before and after the yielding of the tensile steel bars as shown in Fig. 16. Before the yielding of the steel bars, due to the large elastic modulus of the steel, the steel bars provided higher tensile strength than the I-beam. The tensile force offered by the bottom flange was not more than $30 \%$ of the tensile force offered by the tensile steel bars in Stage (O-A). After the yielding of the steel bars, the stress of the steel bars did not increase and the I-beam started to carry more load. Therefore, the tensile force of the flange increased significantly in Stage (A-B). When the ultimate load was reached, the tensile force of the flange actually had exceeded the force of the steel bars as shown in Fig. 16a. The large tensile force offered by the bottom flange confirmed the I-beam could provide high flexural strength to the composite beam.

In Group F, the tensile force provided by the bottom flange increased significantly until the ultimate load was reached. The reason for this is that the I-beam and GFRP bars have similar modulus of elasticity, so the increment of the stress for both components was similar. Due to the larger crosssection of the flange, the tensile force of the bottom flanges was larger than that of GFRP bars. For example, the cross-section of the bottom flange was about 3 times of the cross-section of the GFRP bars in Specimen F0.46M, as a result, the tensile force of the flange was always about 3 times of that in the GFRP bars.

Based on the comparison of the tensile force, it is believed that the I-beam could offer high flexural strength to the beam specimens. Especially when the I-beam and the tensile steel bars were used together, two parts could carry the load at different stages of the tests. However, when the I-beam and GFRP bars were used to reinforce the composite beams, the I-beam failed quickly due to the brittle failure of the GFRP bars. 


\subsubsection{Effect of different flanges of I-beam}

401 The top flanges of the I-beam were used for compression in the composite beams. Fig. 17a shows the compressive strain curves of the top flanges in the composite beams. At the start of the test, the stable increase of the compressive strain confirmed the top flanges could offer the compressive strength to the beam specimens. After the ultimate load, the I-beam failed and the compressive strain almost decreased to zero, which reflected that the top flange could not contribute to the flexural strength anymore.

407

The bottom flanges showed different behaviour in comparison with the top flanges as shown in Fig. 17b. Initially, the bottom flanges could provide a large tensile strength, which was confirmed by the almost linear increase of the tensile strain. Afterwards, the maximum tensile strain and the ultimate load of the corresponding specimen were achieved at the same time. Finally, all the tensile strain was stable at a large value after experiencing a slight drop at the maximum strain. The large tensile strain after the ultimate load showed that the I-beams could still provide a high flexural strength even though the beam specimens had failed.

In addition, it is noticed that the maximum compressive strain was about $40 \%-70 \%$ of the ultimate compressive strain (0.0097) for the composite beams (Fig. 17a). However, the maximum tensile strain reached about $70 \%-80 \%$ of the ultimate tensile strain (0.01) for all the composite beams (Fig. 17b). Therefore, the bottom flanges can be more efficiently utilized when the I-beam is encased in the concrete to reinforce the beam specimen.

\subsubsection{Effect of locations of I-beam}

The I-beam was placed at two different locations in this study. Based on the test results, the ultimate load slightly decreased by $3 \%$ when the I-beam was transferred by $30 \mathrm{~mm}$ from the middle to the bottom of the cross-section in Group S, and the decrease was about 5\% in Group F. Since the decrease (3\% and 5\%) was small, the effect of the location of the I-beam was negligible in this study. 
However, for the beam members, the load-carrying capacity should be improved when the tensile materials are placed closer to the tension side. As an initial assessment of the flexural behaviour of such composite beams, the randomness of the experimental results cannot be excluded in this study. More analysis should be conducted to investigate the effect of locations of the encased I-beam.

\section{Conclusions}

This paper presents the test results of five beam specimens under four-point bending, including one traditional beam and four composite beams reinforced with GFRP I-beam. The proposed composite beam in this study was reinforced with the I-beam and longitudinal tensile steel bars. The parameters investigated include the location of the I-beam and the type of the tensile bars. Based on the experimental results and analysis, the following conclusions are drawn:

1. The proposed composite beams possess a ductile response and higher ultimate load than the reference RC beam. The encased I-beam can provide high flexural strength and additional shear strength, and the tensile steel bars can contribute to high ductility and ensure the bending stiffness of the composite beams.

2. The yield point of the composite beams is controlled by the tensile steel bars, and the ultimate load is governed by the I-beam.

3. The bottom flanges of the I-beam are more efficiently utilized than the top flanges in the composite beams. Moreover, the bottom flanges can offer a high tensile strength even after the ultimate load, while the top flanges have almost negligible influence after the ultimate load is reached.

4. Slip occurs between the concrete and the I-beam, which reduces the load-carrying capacity to some extent. Some roughening measures are suggested to improve the bond resistance at the interface, for example, sand coating or using additional mechanical connectors.

5. The locations of the I-beam have little effect on the ultimate load of the beam specimens in this 
study. As an initial assessment of such composite beams, the randomness of the experimental result should be taken into consideration, and more systematic studies are desirable to further evaluate the effect of different locations of the I-beam.

456

457 This type of composite beam displays superior flexural response in this preliminary evaluation, 458 including the flexural stiffness, ductility as well as ultimate load. Further studies will focus on the 459 shear behaviour and more parameters will be taken into consideration. It is believed that the proposed 460 composite beam is beneficial for the application of the pultruded profiles in the construction industry.

\section{Acknowledgments}

462 This experimental study was conducted at the strong floor lab of the School of Civil, Mining and 463 Environmental Engineering at the University of Wollongong, Australia. The authors express their 464 sincere appreciation to the Senior Technical Officer Mr. Cameron Neilson for his great help during the 465 process of testing. The second author is grateful for the financial support from the China Scholarship 466 Council and the University of Wollongong, Australia. 


\section{Reference}

468 [1] Smith ST, Teng JG. FRP-strengthened RC beams. II: assessment of debonding strength models. 469 Engineering Structures 2002; 24(4):397-417.

470 [2] Chen JF, Teng JG. Shear capacity of FRP-strengthened RC beams: FRP debonding. Construction 471 and Building Materials 2003; 17(1):27-41.

472 [3] Teng JG, Hu YM. Behaviour of FRP-jacketed circular steel tubes and cylindrical shells under axial 473 compression. Construction and Building Materials 2007; 21(4):827-38.

[4] Walker RA, Karbhari VM. Durability based design of FRP jackets for seismic retrofit. Composite 475 Structures $2007 ; 80(4): 553-68$.

[5] Hadi MNS, Wang W, Sheikh MN. Axial compressive behaviour of GFRP tube reinforced concrete columns Construction and Building Materials. 2015; 81:198-207.

[6] Wang W, Sheikh MN, Hadi MNS. Behaviour of perforated GFRP tubes under axial compression. Thin-Walled Structures 2015; 95:88-100.

480

[7] Sharbatdar MK, Saatcioglu M, Benmokrane B. Seismic flexural behavior of concrete connections reinforced with CFRP bars and grids. Composite Structures 2011 ;93(10):2439-49.

[8] Miàs C, Torres L, Guadagnini M, Turon A. Short and long-term cracking behaviour of GFRP reinforced concrete beams. Composites Part B: Engineering 2015 ;77:223-31.

[9] Keller T. Recent all-composite and hybrid fibre-reinforced polymer bridges and buildings. Progress in Structural Engineering and Materials 2001; 3(2):132-40.

[10] Girão Coelho AM, Mottram JT, Harries KA. Bolted connections of pultruded GFRP: Implications of geometric characteristics on net section failure. Composite Structures 2015; 131:87884.

[11] Nguyen H, Mutsuyoshi H, Zatar W. Hybrid FRP-UHPFRC composite girders: Part 1 - 
[13] Kwan WH, Ramli M. Indicative performance of fiber reinforced polymer (FRP) encased beam in flexure. Construction and Building Materials 2013; 48:780-8.

[14] Maria Antonietta Aiello LO. Structural Performances of Concrete Beams with Hybrid (FiberReinforced Polymer-Steel) Reinforcements. Journal of Composites for Construction 2002; 6(2):13340.

[15] Lau D, Pam HJ. Experimental study of hybrid FRP reinforced concrete beams. Engineering Structures 2010; 32(12):3857-65.

[16] Li X, Lv H, Zhou S. Flexural behavior of GFRP-reinforced concrete encased steel composite beams. Construction and Building Materials 2012; 28(1):255-62.

[17] Idris Y, Ozbakkaloglu T. Flexural behavior of FRP-HSC-steel composite beams. Thin-Walled Structures 2014; 80:207-16.

[18] El Refai A, Abed F, Al-Rahmani A. Structural performance and serviceability of concrete beams reinforced with hybrid (GFRP and steel) bars. Construction and Building Materials 2015; 96:518-29.

[19] Hawileh RA. Finite element modeling of reinforced concrete beams with a hybrid combination of steel and aramid reinforcement. Materials and Design 2015; 65: 831-839.

[20] Kara IF, Ashour AF, Köroğlu MA. Flexural behavior of hybrid FRP/steel reinforced concrete beams. Composite Structures 2015;129(0): 111-121.

510 [21] Fam AZ. Flexural Behavior of Concrete-Filled Fiber-Reinforced Polymer Circular Tubes. Journal 511 of Composites for Construction 2002; 6(2):123-32. 
513 double-skin tubular members. Journal of Composites for Construction 2006; 10(5):443-52.

514 [23] AS 1391-2007. Metallic materials-Tensile testing at ambient temperature, Standards Australia 515 Limited, NSW; 2007.

516 [24] Treadwell: Custom Fibreglass Reinforced Plastic (FRP) \& Underfoot Products. 58 Deeds Rd, 517 North Plympton, SA Australia.<http://www.treadwellgroup.com.au/> (accessed on April 2016).

518 [25] ASTM D7565/D7565M-10. Standard test method for determining tensile properties of fibre 519 reinforced polymer matrix composites used for strengthening of civil structures. United States: ASTM $520 \quad$ International; 2010.

521 [26] ASTM D695. Standard test method for compressive properties of rigid plastics. United States: $522 \quad$ ASTM international. 2002.

523 [27] ISO 527-1. Plastics: Determination of tensile properties. European Committee for 524 Standardisation, Brussels, Belgium; 1996.

525 [28] Naaman AE, Jeong SM. Structural dutility of concrete beams prestressed with FRP tendons. 526 Proceedings of the second international RILEM symposium (FRPRCS-2): non-metallic (FRP) for 527 concrete structures Ghent, Belgium 1995:379-86.

528 [29] Alsayed SH, Alhozaimy AM. Ductility of concrete beams reinforced with FRP bars and steel 529 fibers. Journal of composite materials 1999; 33(19):1972-806.

530 [30] Jo BW, Tae GH, Kwon BY. Ductility Evaluation of Prestressed Concrete Beams with CFRP 531 Tendons. Reinforced Plastics and Composites 2004; 23:843-59. 


\section{List of Tables:}

533 Table 1. Configuration of Specimens

534 Table 2. Tensile Properties of Steel and GFRP bars

535 Table 3. Tensile and compressive properties of I-beam

536 Table 4. Experimental Results of Beam Specimens

537 Table 5. Bending stiffness (EI) of specimens

538 Table 6. Energy Ductility

539 


\section{List of Figures:}

541 Figure. 1. Cross-sections of composite beams (a) Cross-section $\mathrm{A}^{[12]}$, (b) Cross-section $\mathrm{B}^{[13]}$, (c)

542 Proposed cross-section in this study

543 Figure. 2. Cross-sections of beam specimens (mm) (a) Specimen RC, (b) Specimen S0.57M, (c)

544 Specimen S0.57B, (d) Specimen F0.46M, (e) Specimen F0.46B

545 Figure. 3. Material testing of GFRP bars (mm) (a) Dimension of coupon, (b) Testing setup

546 Figure. 4. Material testing of GFRP I-beam (mm)

547 Figure. 5. Fabrication of beam specimens (a) Fixing I-beam into steel cages, (b) Placing steel cages 548 into formwork

549 Figure. 6. Test setup (mm)

550 Figure. 7. Setup of LVDTs (a) LVDTs in the shear span, (b) LVDT in the midspan

551 Figure. 8. Setup of strain gauges (a) Strain gauges at Specimen RC, (b) Strain gauges at the composite 552 beam specimens

553 Figure. 9. Load-midspan deflection behaviour

554 Figure. 10. Failure mode of beam specimens (a) Failure mode of Specimen RC, (b) Failure mode of 555 Specimen S0.57M, (c) Failure mode of Specimen S0.57B, (d) Failure mode of Specimen F0.46M, (e)

556 Failure mode of Specimen F0.46B

557 Figure. 11. Strain-midspan deflection curves versus load-midspan delfection curves (a) Specimen

558 S0.57M, (b) Specimen S0.57B

559 Figure. 12.Ductility mode in this study

560 Figure. 13. Comparison of ductility 
561 Figure. 14. Distribution of cracks at ultimate load (a) Specimen RC, (b) Specimen S0.57M, (c) 562 Specimen S0.57B, (d) Specimen F0.46M, (e) Specimen F0.46B

563 Figure. 15. Slip of composite beams (a) Specimen S0.57M, (b) Specimen S0.57B, (c) Specimen 564 F0.46M, (d) Specimen F0.46B

565 Figure. 16. Comparison of the tensile force (a) Specimen S0.57M, (b) Specimen S0.57B, (c) 566 Specimen F0.46M, (d) Specimen F0.46B

567 Figure. 17. Strain-midspan deflection curves (a) Strain curves of the top flanges, (b) Strain curves of 568 the bottom flanges. 
Table 1

Configuration of Specimens

\begin{tabular}{|c|c|c|c|c|c|c|c|c|c|c|c|c|}
\hline \multirow{2}{*}{ Group } & \multirow{2}{*}{ Specimen } & \multicolumn{3}{|c|}{ Top bars } & \multicolumn{3}{|c|}{ Bottom bars } & \multicolumn{3}{|c|}{ Stirrups } & \multirow{2}{*}{$\begin{array}{c}\text { GFRP I- } \\
\text { beam (mm) }\end{array}$} & \multirow{2}{*}{$\begin{array}{l}\text { Location of } \\
\text { I-beam } \\
\quad(\mathrm{mm})\end{array}$} \\
\hline & & Material & $\begin{array}{c}\text { Diameter } \\
(\mathrm{mm})\end{array}$ & $\begin{array}{l}\text { Number } \\
\text { of bars }\end{array}$ & Material & $\begin{array}{c}\text { Diameter } \\
(\mathrm{mm})\end{array}$ & $\begin{array}{l}\text { Number } \\
\text { of bars }\end{array}$ & Material & $\begin{array}{c}\text { Diameter } \\
(\mathrm{mm})\end{array}$ & $\begin{array}{r}\text { Spacing } \\
(\mathrm{mm})^{\mathrm{a}}\end{array}$ & & \\
\hline Reference & $\mathrm{RC}$ & Steel & 10 & 2 & Steel & 16 & 4 & Steel & 10 & $\begin{array}{c}60 \text { or } \\
80\end{array}$ & - & - \\
\hline Group S & S0.57M & Steel & 10 & 2 & Steel & 16 & 2 & Steel & 10 & $\begin{array}{c}60 \text { or } \\
80\end{array}$ & $200 \times 100 \times 10$ & Middle \\
\hline \multirow{2}{*}{ Group F } & S0.57B & Steel & 10 & 2 & Steel & 16 & 2 & Steel & 10 & $\begin{array}{c}60 \text { or } \\
80\end{array}$ & $200 \times 100 \times 10$ & $\begin{array}{c}30 \text { below } \\
\text { middle }\end{array}$ \\
\hline & F0.46B & Steel & 10 & 2 & GFRP & 12 & 3 & Steel & 10 & $\begin{array}{c}60 \text { or } \\
80\end{array}$ & $200 \times 100 \times 10$ & $\begin{array}{c}30 \text { below } \\
\text { middle }\end{array}$ \\
\hline
\end{tabular}

${ }^{a}$ The stirrups were spaced at $60 \mathrm{~mm}$ in the shear span and $80 \mathrm{~mm}$ in the pure bending region. 
Table 2.

Tensile Properties of Steel and GFRP Bars

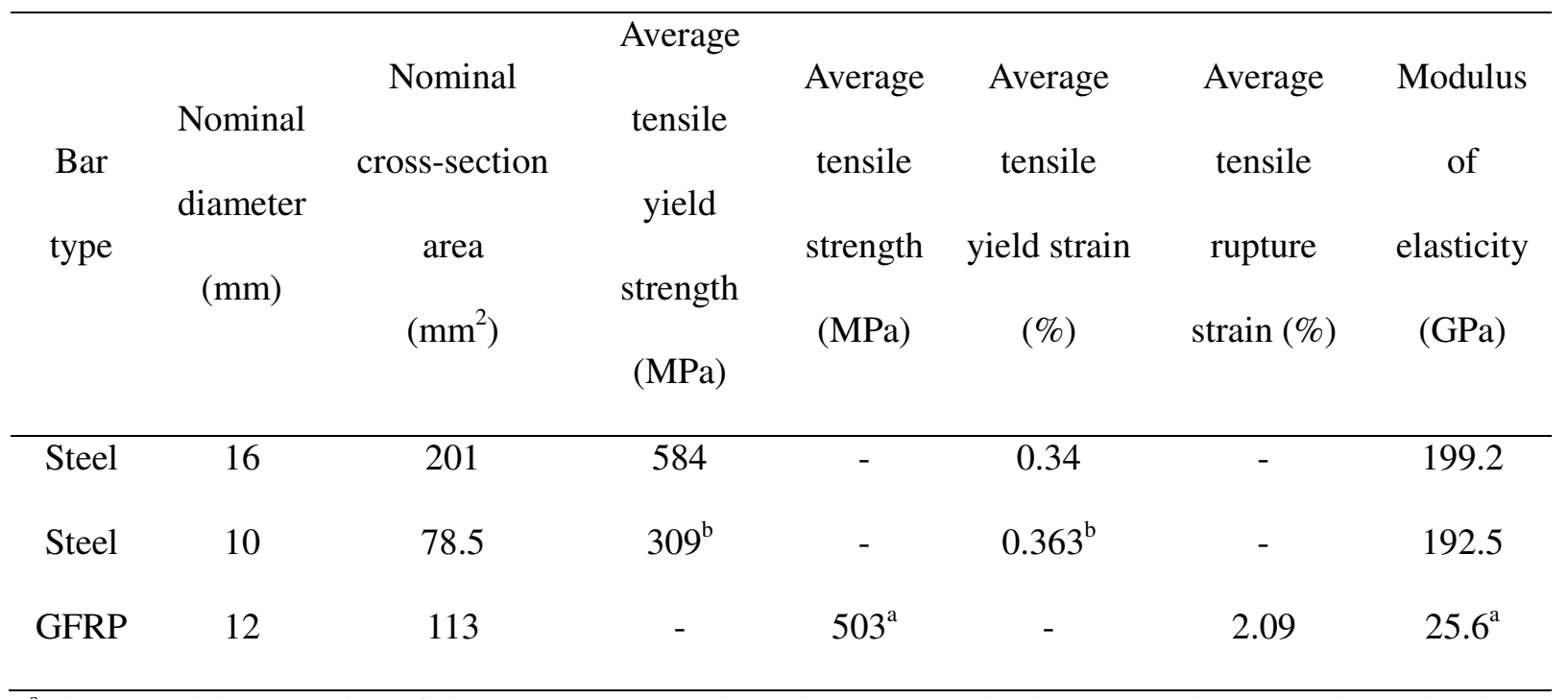

${ }^{\mathrm{a}}$ The material properties of the GFRP bars are based on the nominal cross-section area determined by the nominal diameter.

${ }^{b}$ Determined by the $0.2 \%$ offset method. 
Table 3

Tensile and compressive properties of I-beam

\begin{tabular}{lcc}
\hline Properties & Flange of I-beam & Web of I-beam \\
\hline Tensile strength (MPa) & 381.5 & 353 \\
Tensile strain (\%) & 1.0 & 1.1 \\
Elastic modulus (GPa) & 38.5 & 32.88 \\
Compressive strength (MPa) & 214.2 & 233.8 \\
Compressive strain (\%) & 0.97 & 0.69 \\
Elastic modulus (GPa) & 26.9 & 30.2 \\
\hline
\end{tabular}


Table 4

Experimental Results of Beam Specimens

\begin{tabular}{|c|c|c|c|c|c|c|c|}
\hline Group & Specimen & $\begin{array}{l}\text { Yield load } \\
\left(P_{y}\right)(\mathrm{kN})\end{array}$ & $\begin{array}{l}\text { Ultimate } \\
\text { load }\left(P_{u}\right) \\
(\mathrm{kN})\end{array}$ & $\begin{array}{l}\text { Midspan deflection } \\
\text { at ultimate load }(\Delta) \\
(\mathrm{mm})\end{array}$ & Failure mode & $\begin{array}{c}\text { Ultimate } \\
\text { Moment }\left(M_{u}\right) \\
(\mathrm{kN} . \mathrm{m})\end{array}$ & $\begin{array}{l}\text { Ultimate Slip of I-beam } \\
\qquad(\mathrm{mm})\end{array}$ \\
\hline Reference & $\mathrm{RC}$ & 380 & 380 & 12.2 & $\begin{array}{l}\text { Tensile steel bars yielded } \\
\text { Top concrete crushed }\end{array}$ & 127.3 & - \\
\hline & S0.57B & 314 & 400 & 32.1 & $\begin{array}{l}\text { Tensile steel bars ruptured } \\
\text { Top concrete crushed }\end{array}$ & 134 & 9 \\
\hline
\end{tabular}


Table 5

Bending stiffness $(E I)$ of specimens

\begin{tabular}{cccccc}
\hline & Specimen & Specimen & Specimen & Specimen & Specimen \\
& $\mathrm{RC}$ & S0.57M & S0.57B & F0.46M & F0.46B \\
\hline$P(\mathrm{kN})$ & 380 & 313 & 314 & 357 & 339 \\
$L(\mathrm{~mm})$ & 1740 & 1740 & 1740 & 1740 & 1740 \\
$a(\mathrm{~mm})$ & 670 & 670 & 670 & 670 & 670 \\
$\Delta(\mathrm{mm})$ & 12.2 & 10.8 & 10.2 & 22.9 & 24.1 \\
$E I\left(\times 10^{12}\right)$ & 3.2 & 3.0 & 3.1 & 1.6 & 1.4 \\
$\left(\mathrm{~N} . \mathrm{mm}^{2}\right)$ & & & & & \\
\hline
\end{tabular}


Table 6

Energy Ductility

\begin{tabular}{ccccccc}
\hline Specimen & Slope $S_{1}$ & Slope $S_{2}$ & Slope $S$ & $\begin{array}{c}\text { Total energy } \\
E_{T}(\mathrm{kN} . \mathrm{mm})\end{array}$ & $\begin{array}{c}\text { Elastic energy } \\
E_{E}(\mathrm{kN} . \mathrm{mm})\end{array}$ & $\begin{array}{c}\text { Energy Ductility } \\
\text { RC }\end{array}$ \\
& 36 & 0 & 36 & 20000 & 1800 & 6.1 \\
\hline S0.57M & 35.2 & 3.5 & 27.5 & 29000 & 1136 & 13.2 \\
S0.57B & 34.6 & 3.8 & 28 & 22000 & 1395 & 8.4 \\
F0.46M & 24.1 & 11.4 & 17.8 & 5100 & 3592 & 1.2 \\
F0.46B & 23.6 & 9.6 & 16.6 & 5150 & 3474 & 1.2 \\
\hline
\end{tabular}



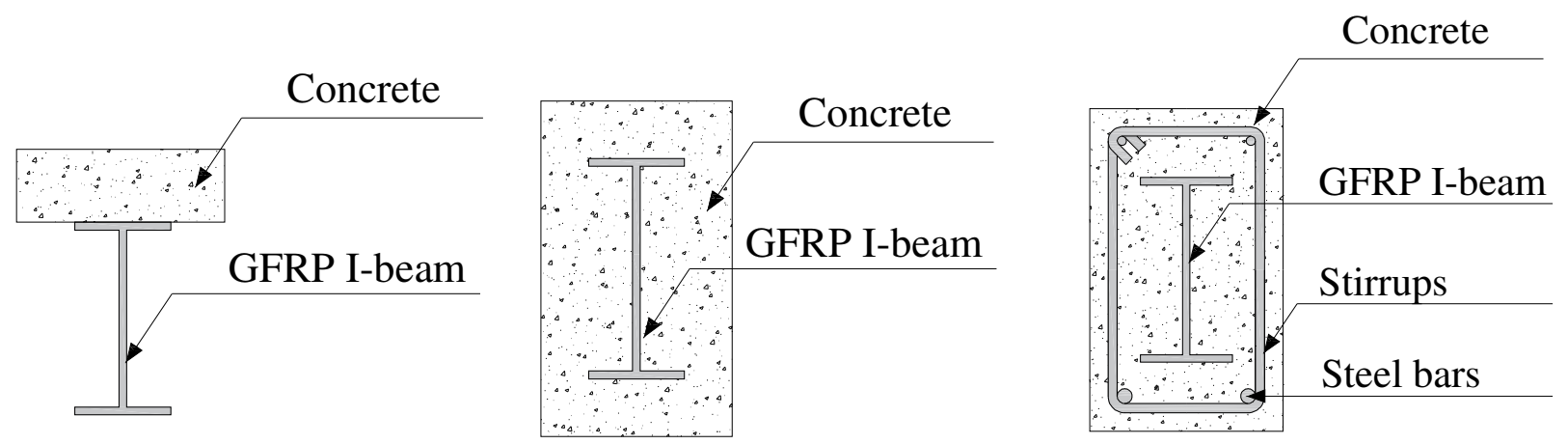

(a) Cross-section $\mathrm{A}^{[12]}$

(b) Cross-section $\mathrm{B}^{[13]}$

(c) Proposed cross-section in this study

Fig. 1. Cross-sections of composite beams 


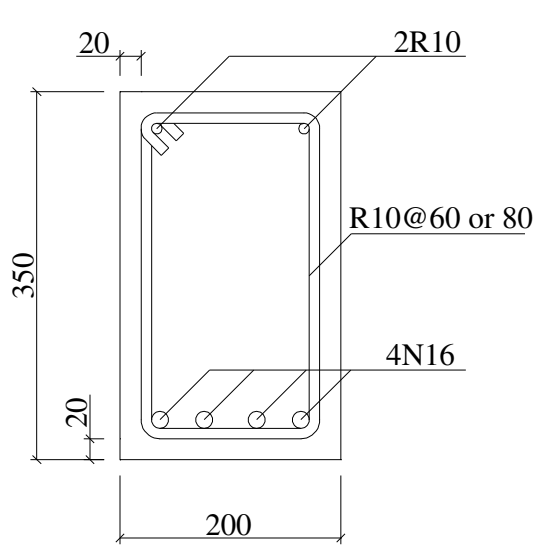

(a) Specimen RC

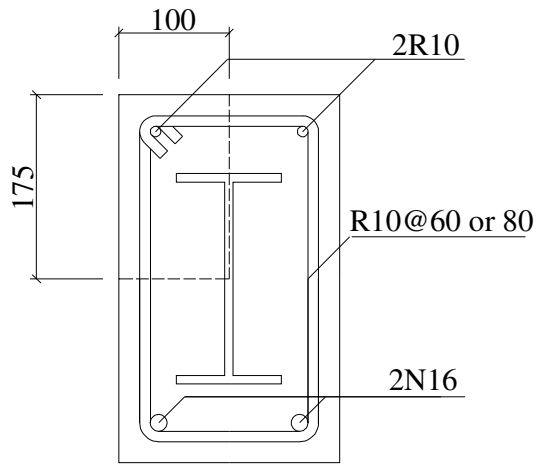

(b) Specimen S0.57M

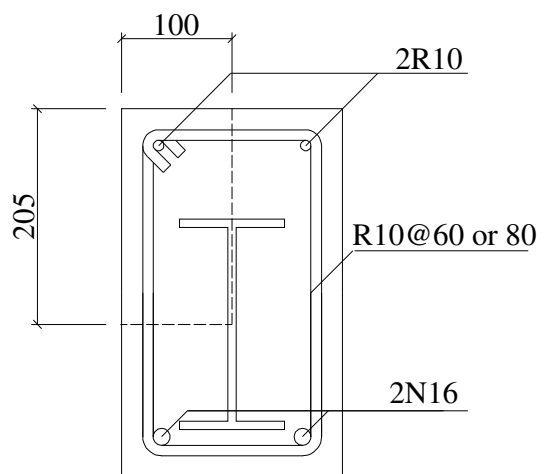

(c) Specimen S0.57B

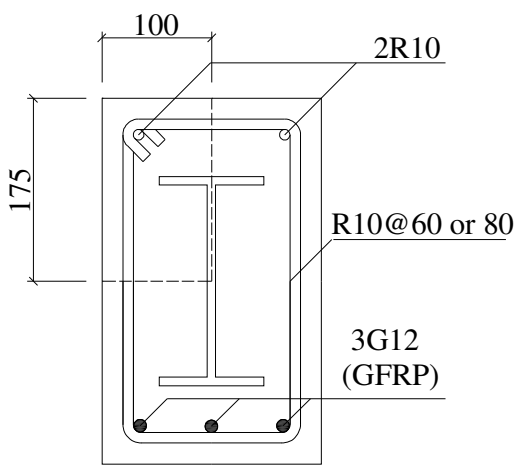

(d) Specimen F0.46M

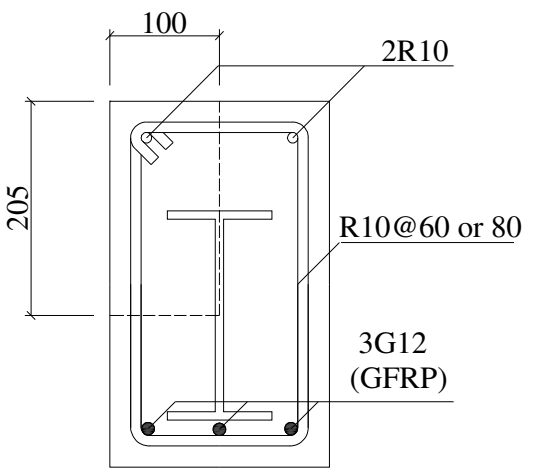

(e) Specimen F0.46B

Fig. 2. Cross-sections of beam specimens (mm) 


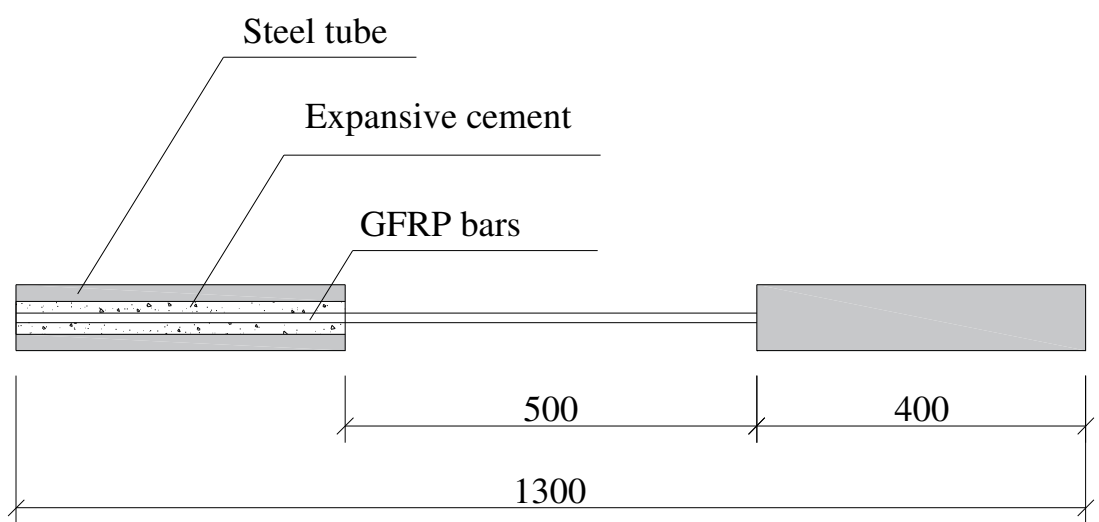

(a) Dimension of coupon

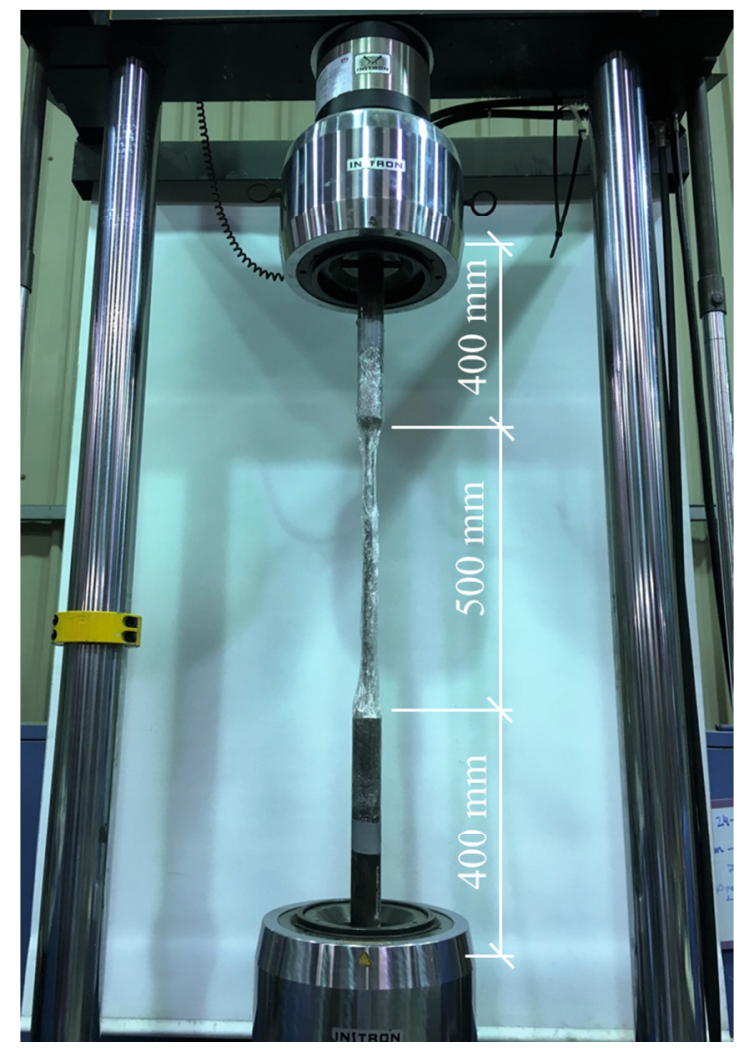

(b) Testing setup

Fig. 3. Material testing of GFRP bars (mm) 


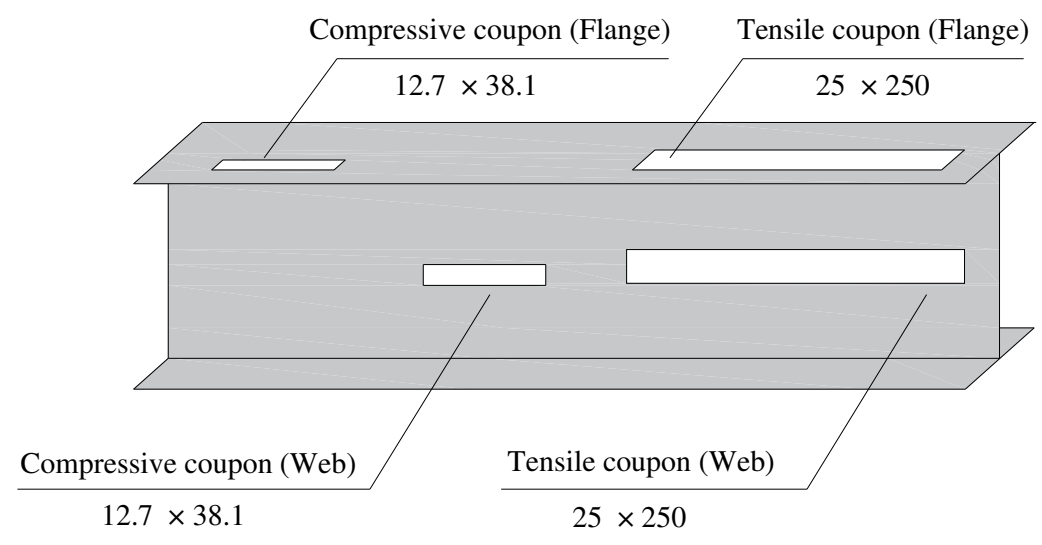

Fig. 4. Material testing of GFRP I-beam (mm) 


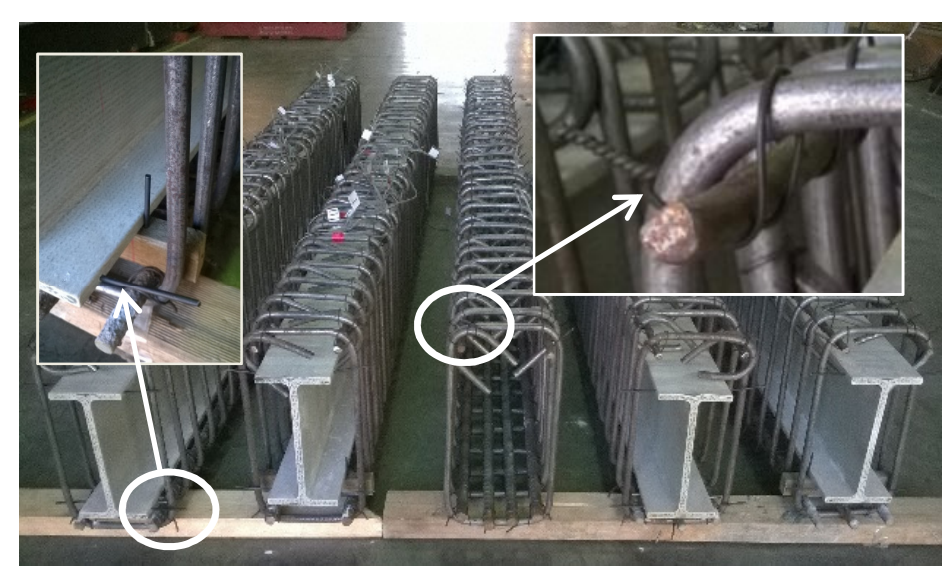

(a) Fixing GFRP I-beam into steel cages

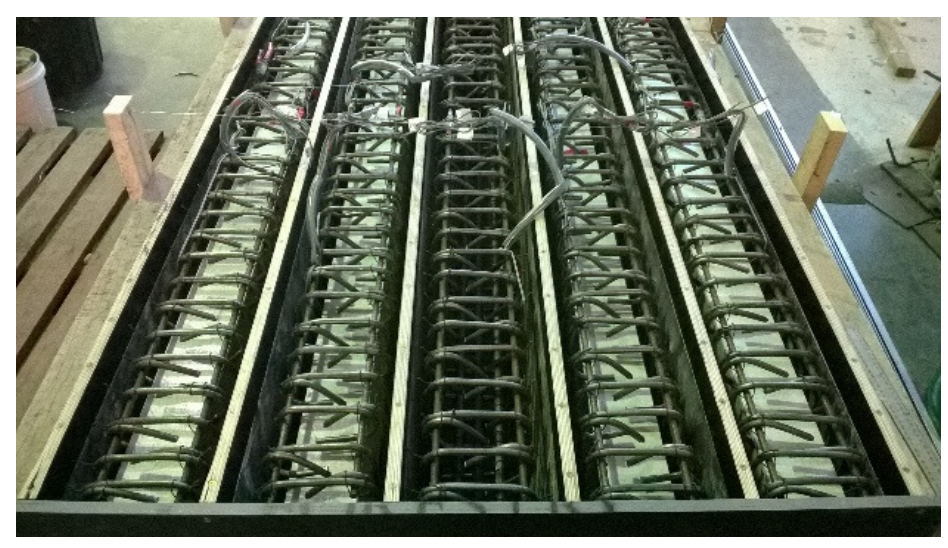

(b) Placing steel cages into formwork

Fig. 5. Fabrication of beam specimens 


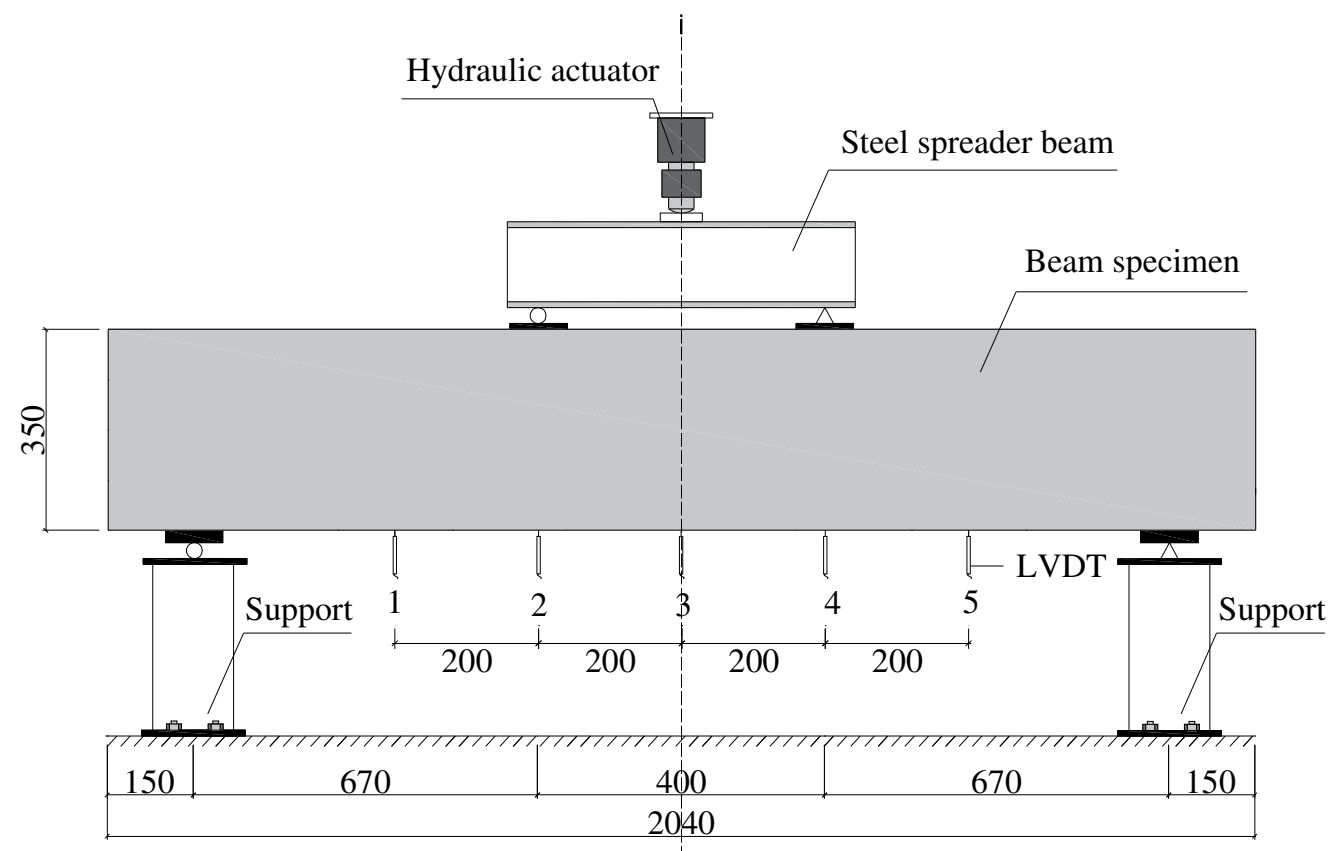

Fig. 6. Test setup (mm) 


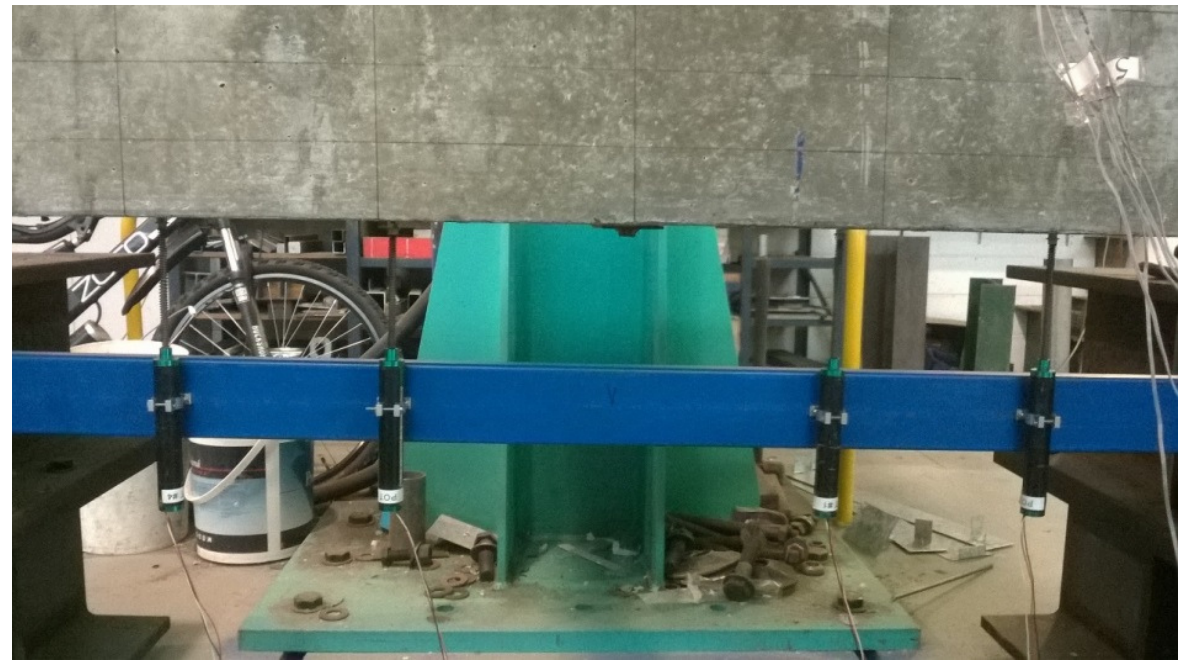

(a) LVDTs in the shear span

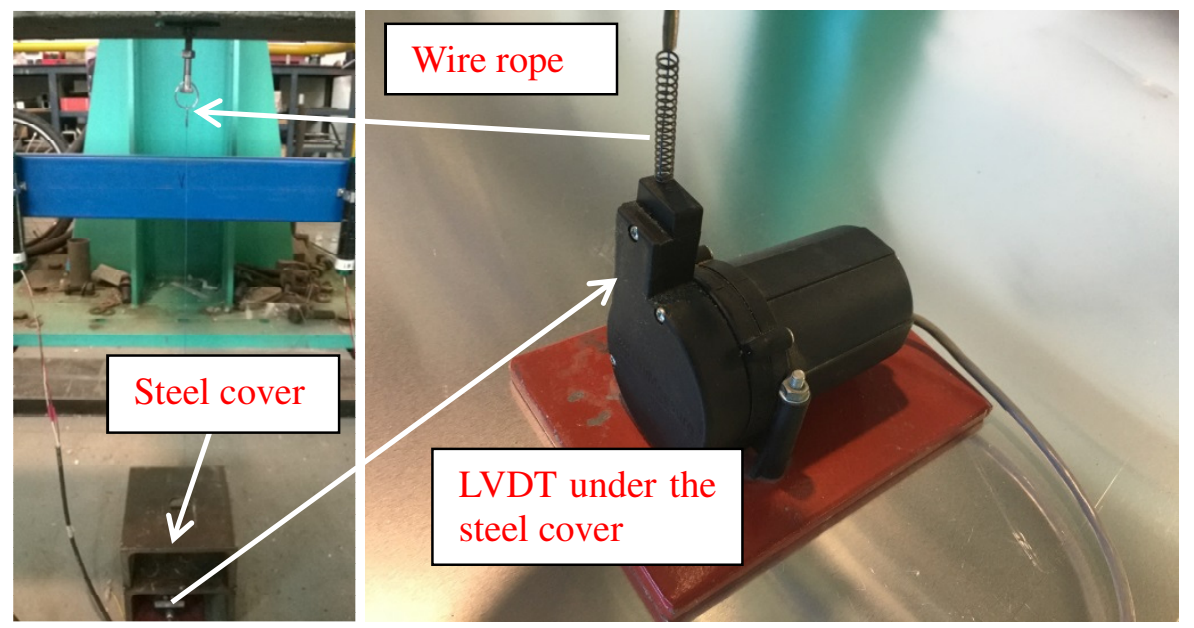

(b) LVDT in the midspan

Fig. 7. Setup of LVDTs 


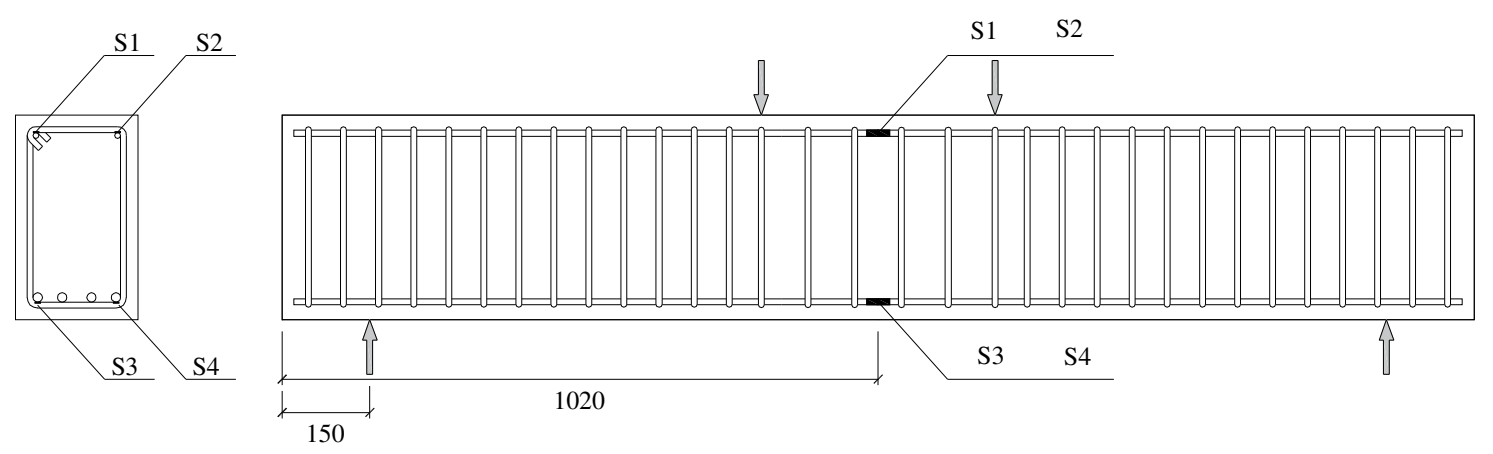

(a) Strain gauges at Specimen RC

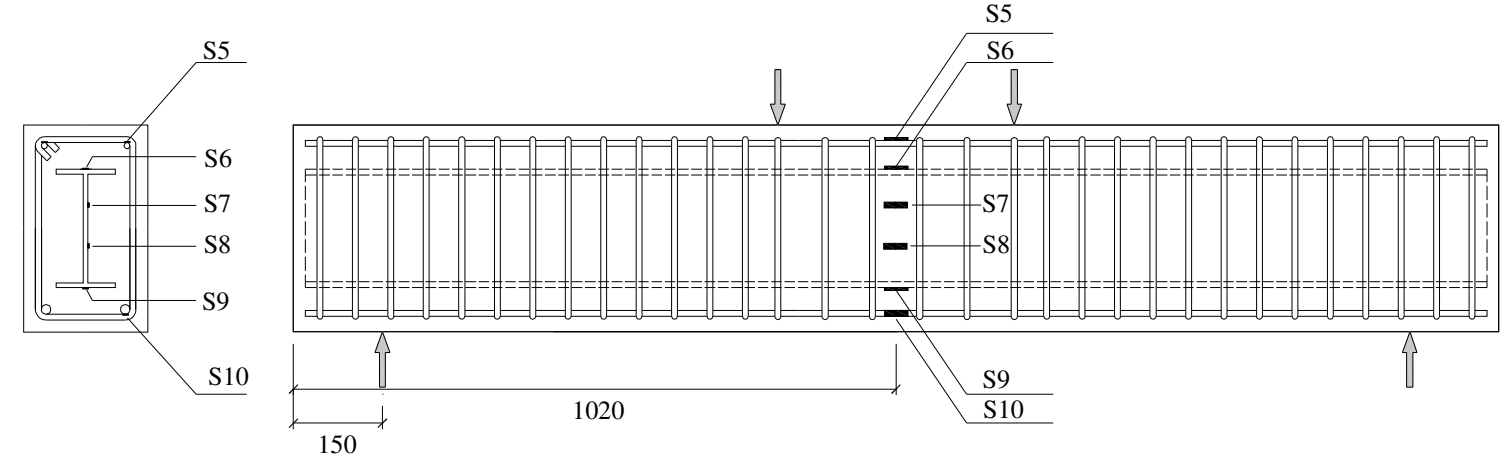

(b) Strain gauges at the composite beam specimens

Fig. 8. Setup of strain gauges 


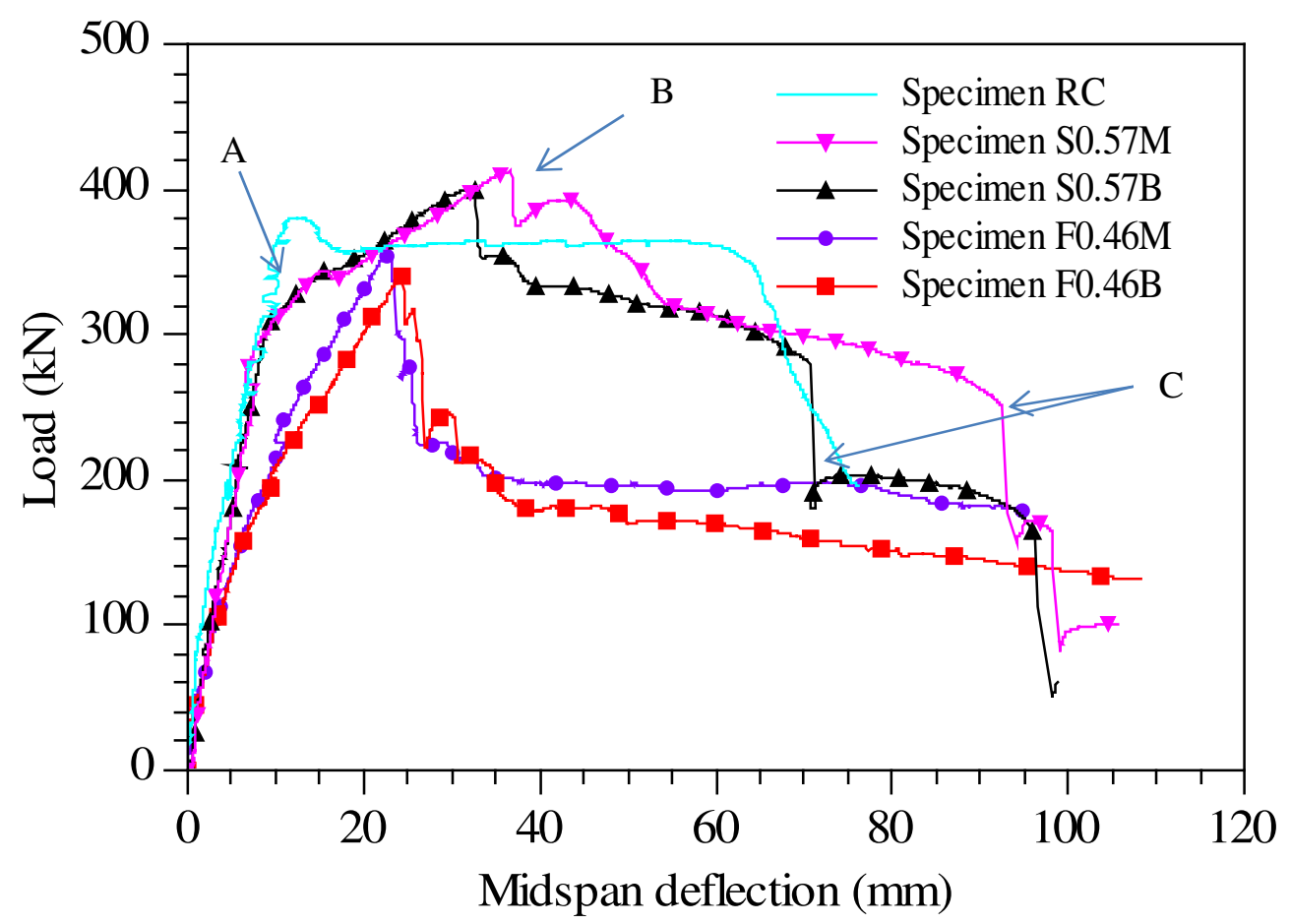

Fig. 9. Load-midspan deflection behaviour 


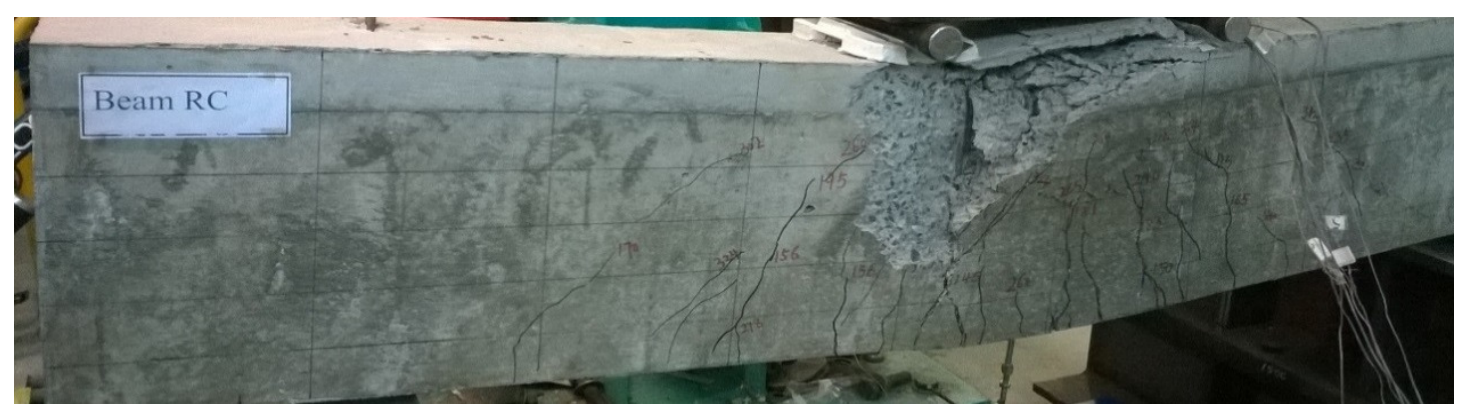

(a) Failure mode of Specimen RC

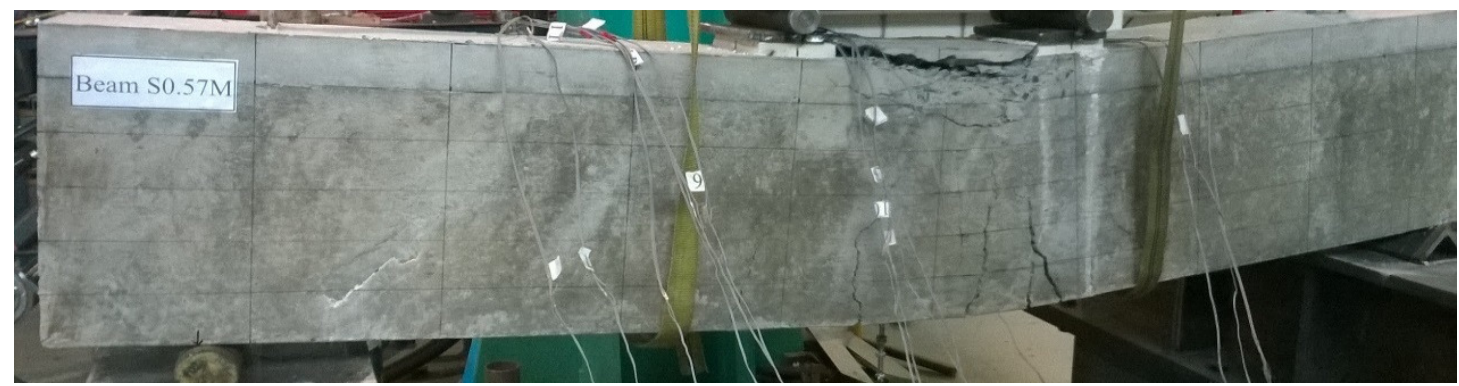

(b) Failure mode of Specimen S0.57M

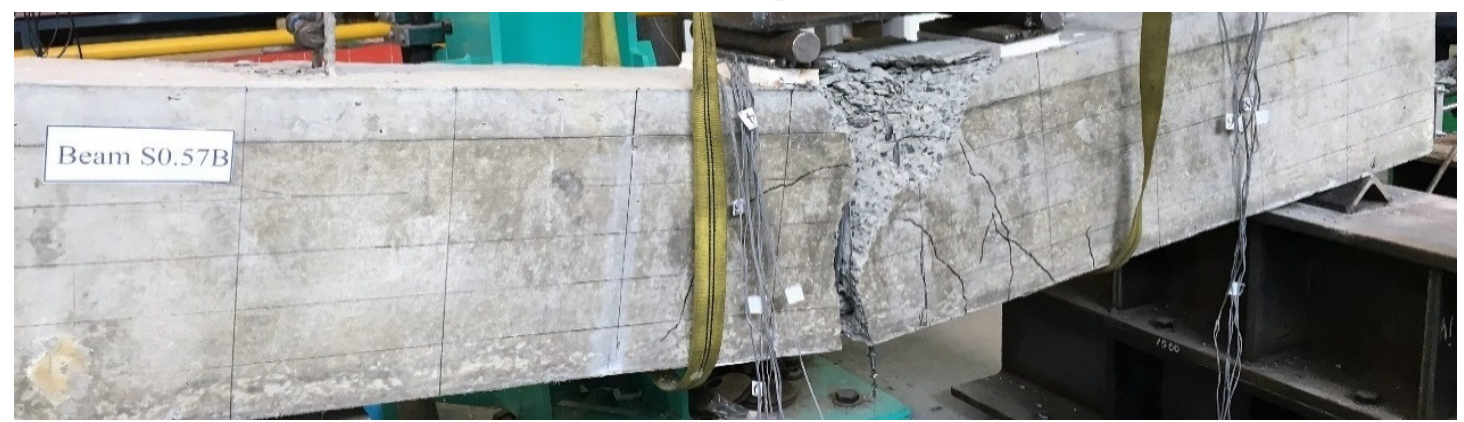

(c) Failure mode of Specimen S0.57B

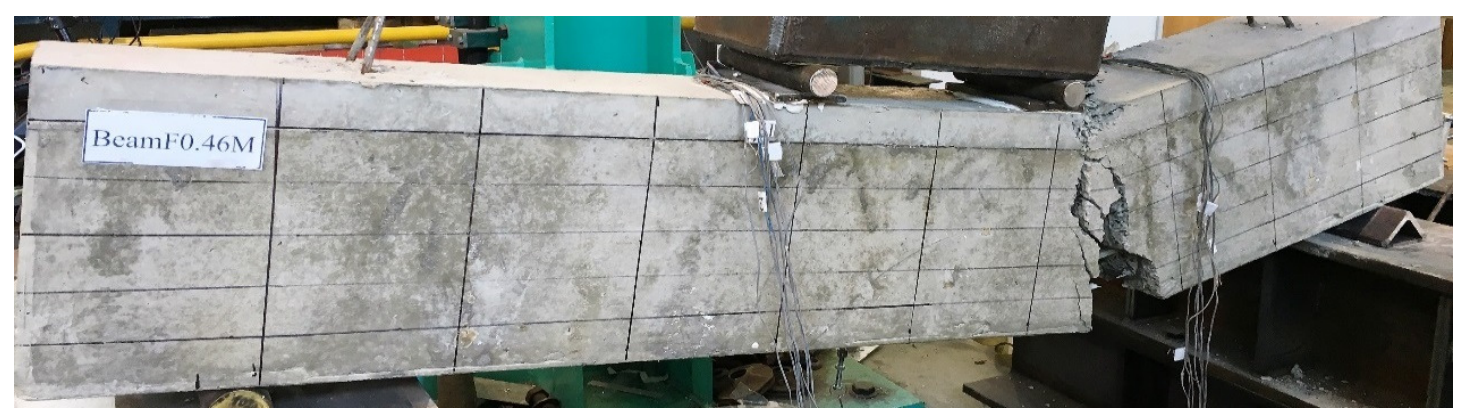

(d) Failure mode of Specimen F0.46M

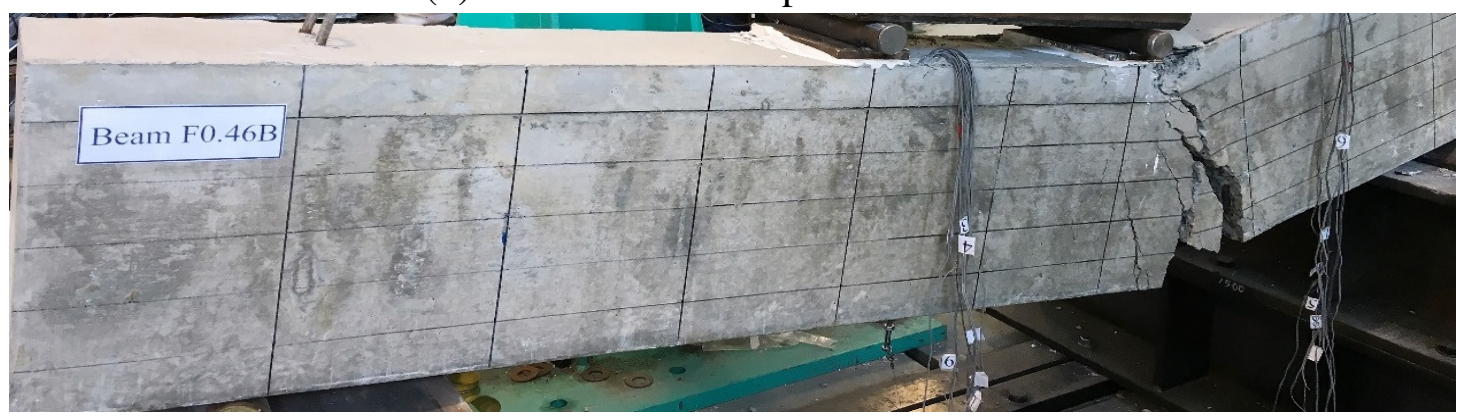

(e) Failure mode of Specimen F0.46B

Fig. 10. Failure modes of beam specimens 

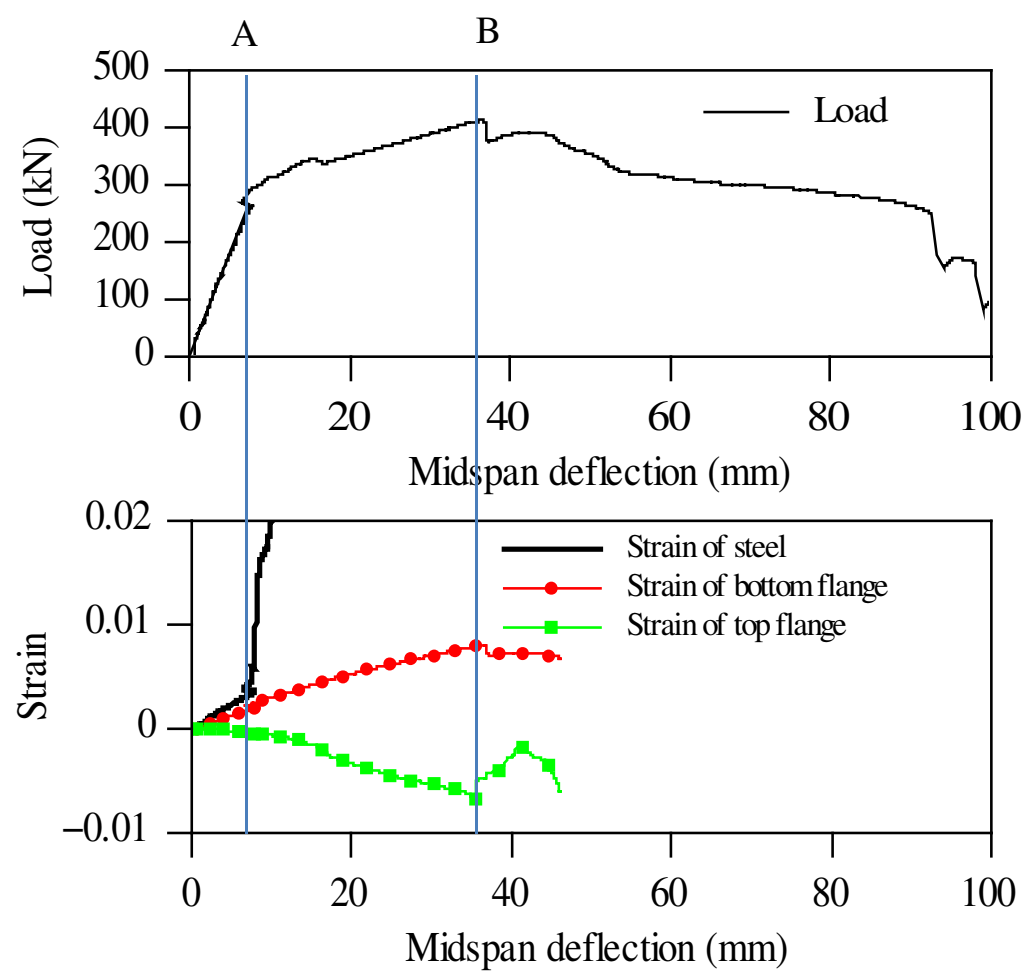

(a) Specimen S0.57M

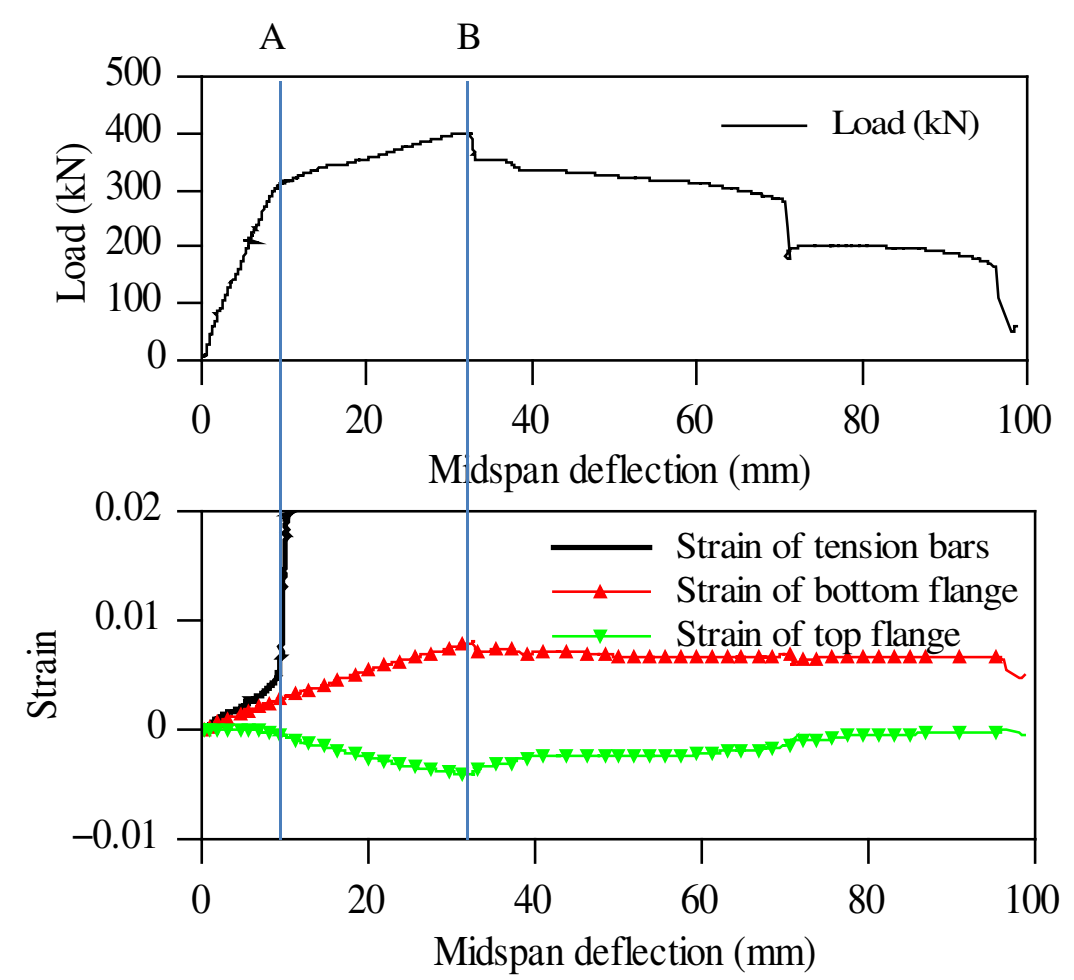

(b) Specimen S0.57B

Fig. 11. Strain-midspan deflection curves versus load-midspan deflection curves 


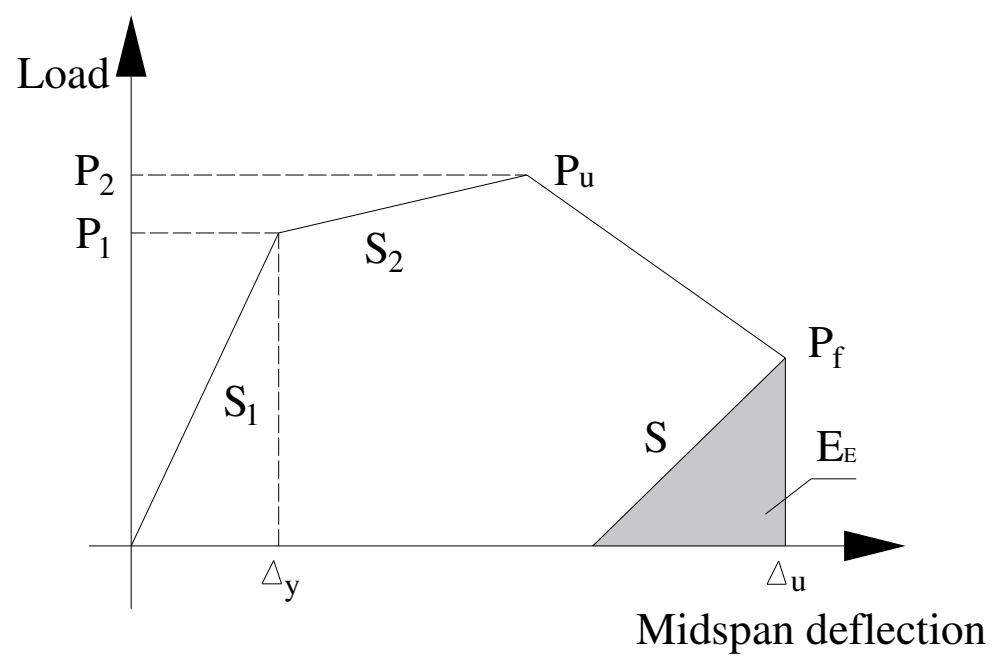

Fig. 12. Ductility mode in this study 


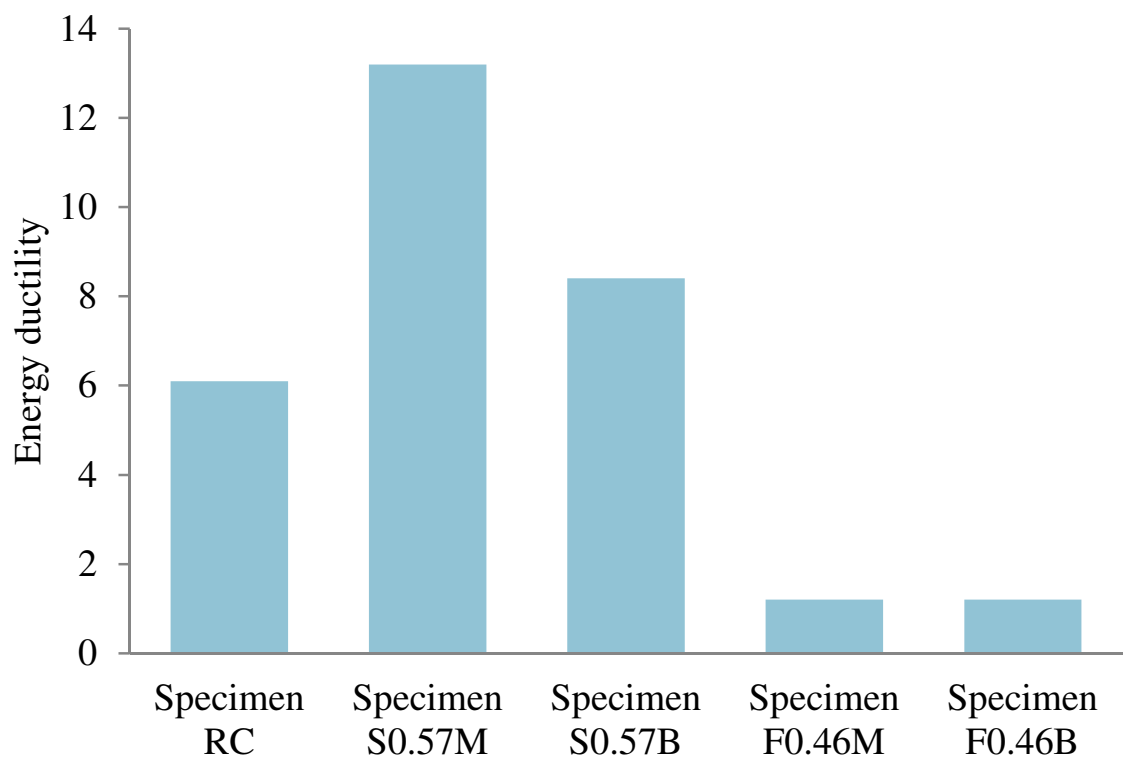

Fig. 13. Comparison of ductility 


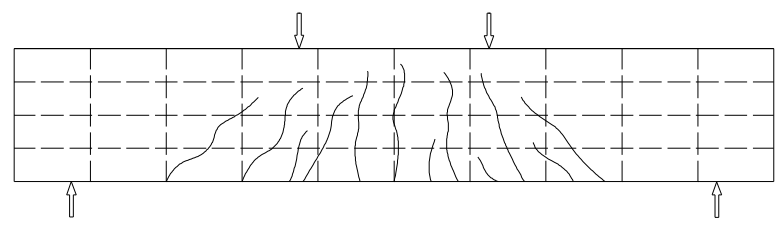

(a) Specimen RC
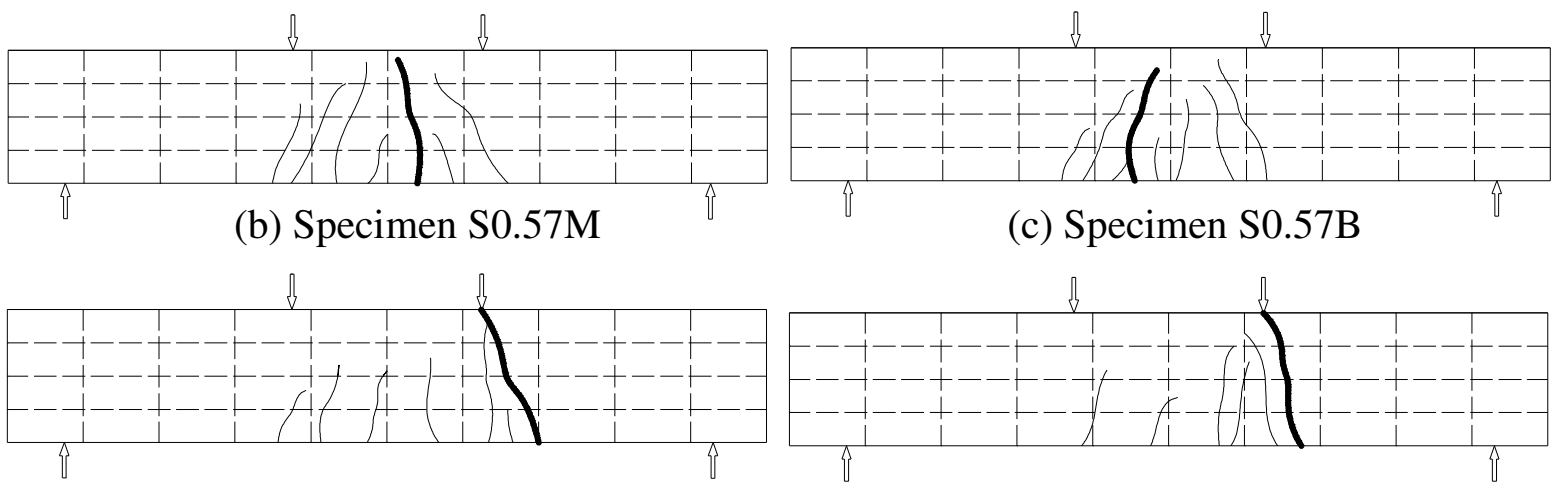

(d) Specimen F0.46M

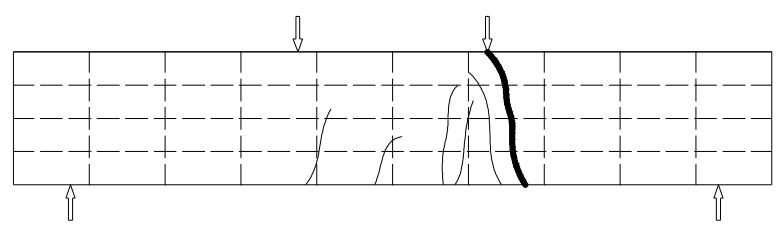

(e) Specimen F0.46B

Fig. 14. Distribution of cracks at ultimate load 


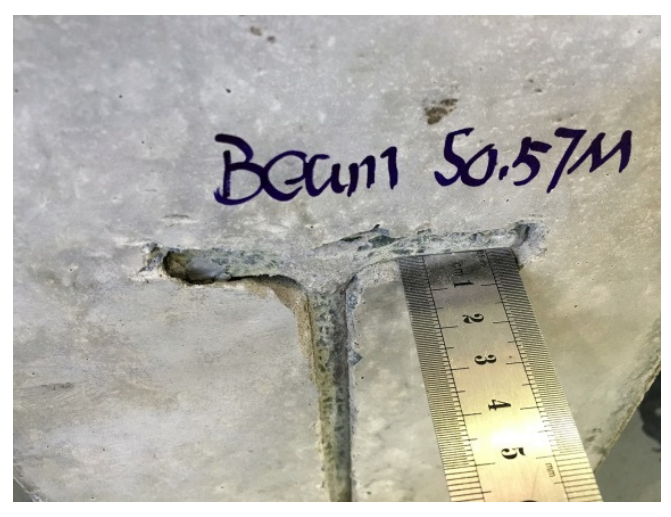

(a) Specimen S0.57M

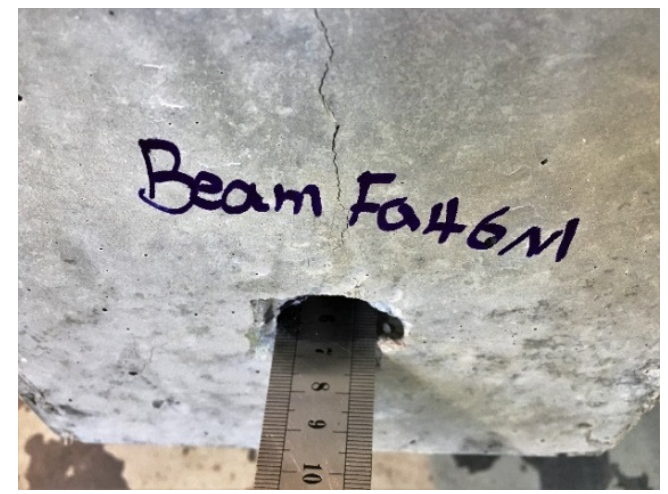

(c) Specimen F0.46M

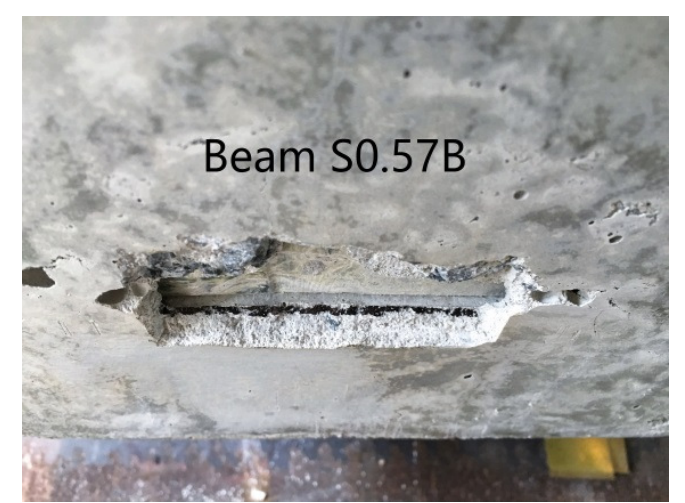

(b) Specimen S0.57B

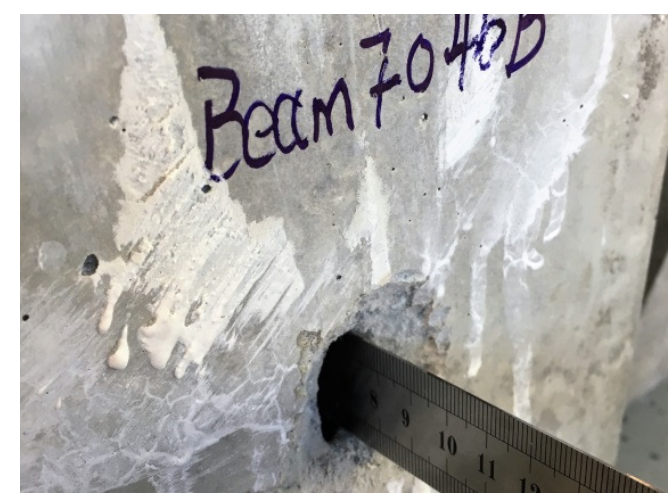

(d) Specimen F0.46B

Fig. 15. Slip of composite beams 


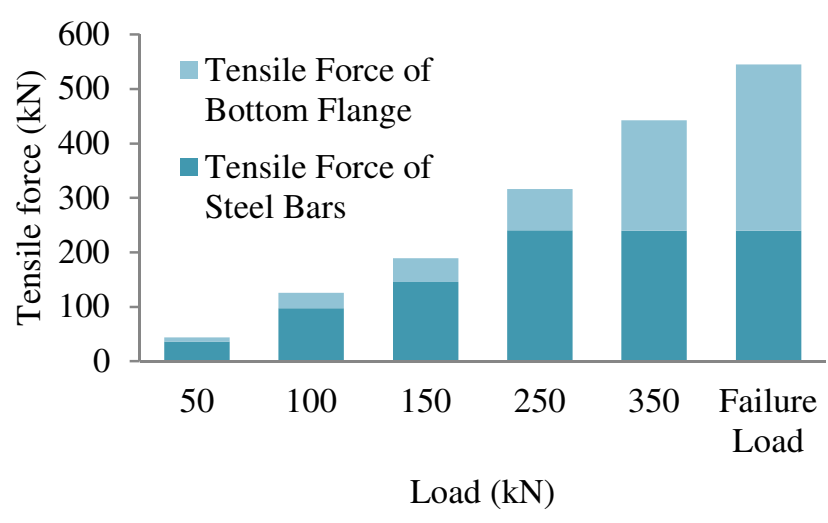

(a) Specimen S0.57M

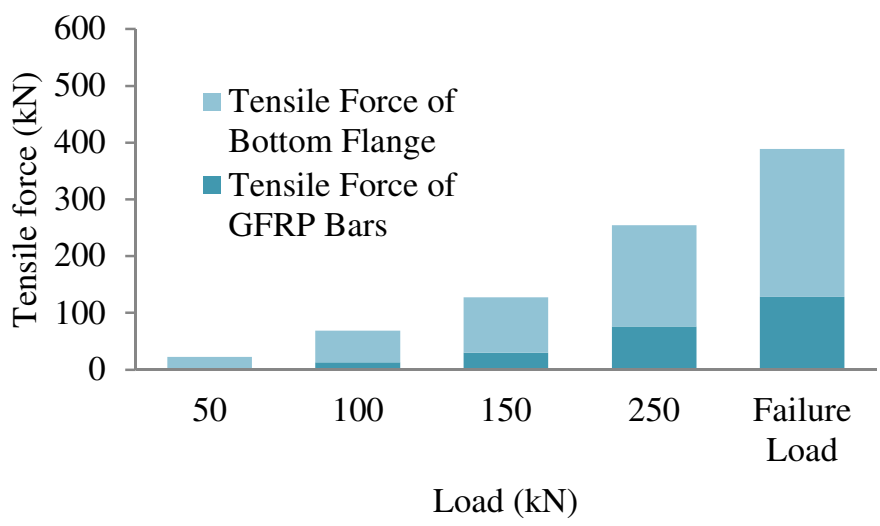

(c) Specimen F0.46M

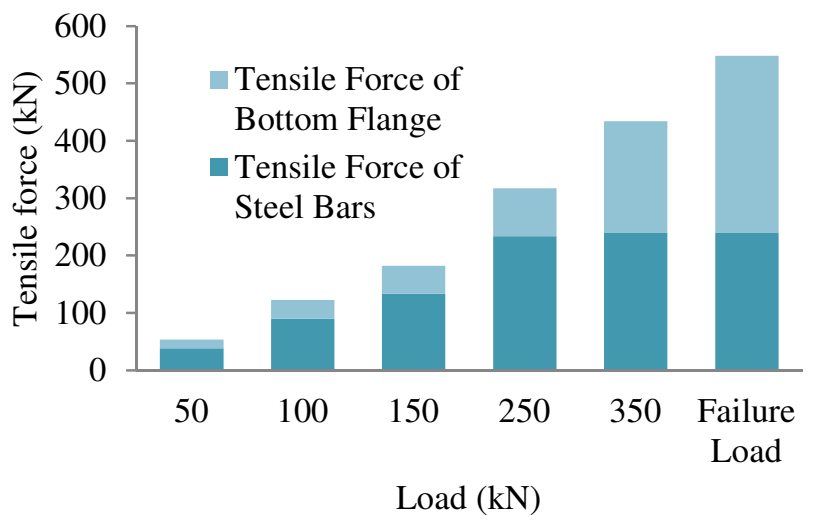

(b) Specimen S0.57B

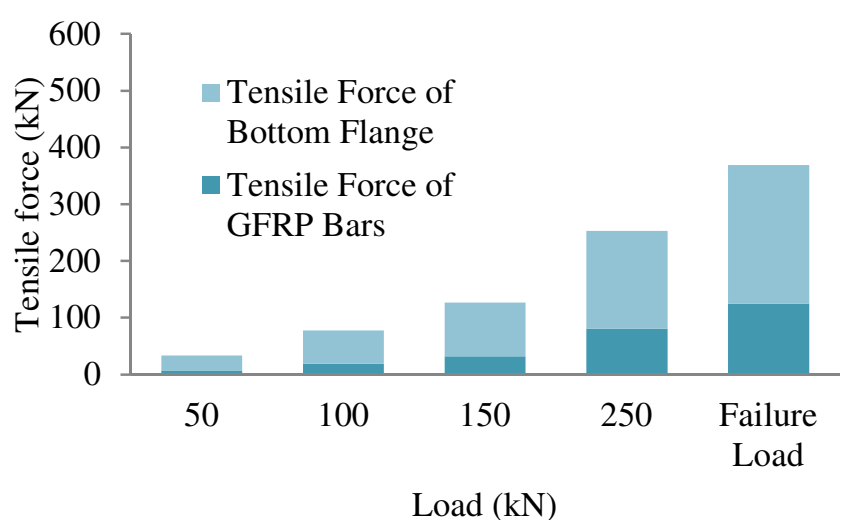

(d) Specimen F0.46B

Fig. 16. Comparison of the tensile force 


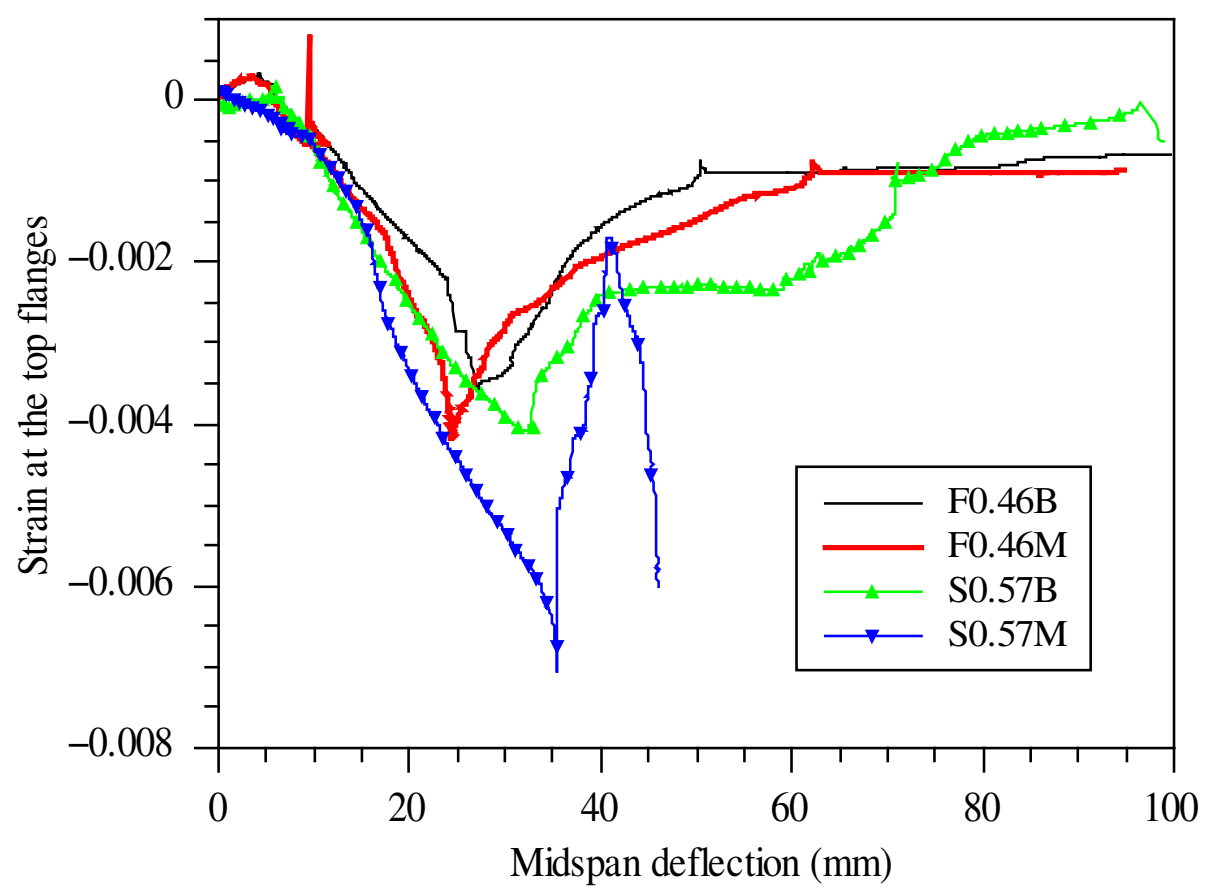

(a) Strain curves of the top flanges

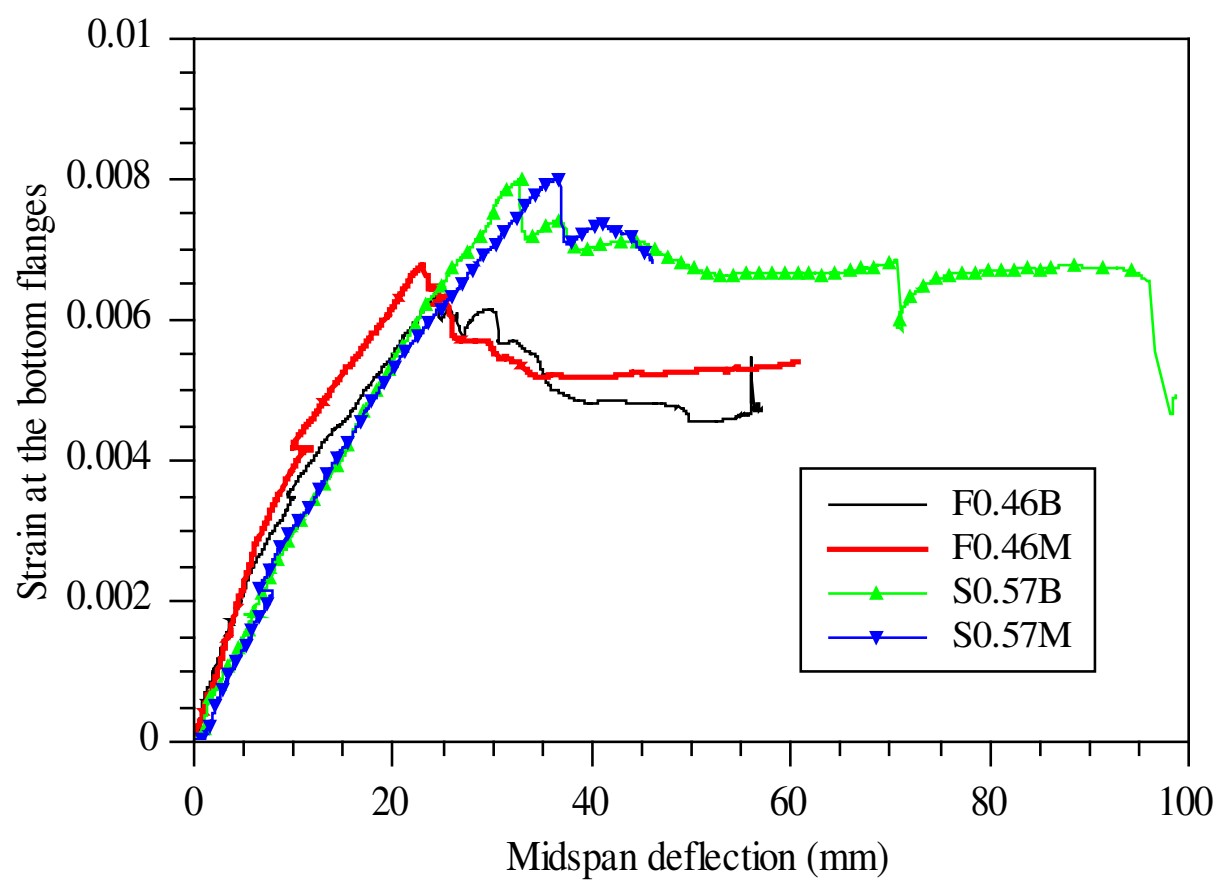

(b) Strain curves of the bottom flanges

Fig. 17. Strain-midspan deflection curves 